Prepared in cooperation with the U.S. Fish and Wildlife Service

\title{
Preliminary Geohydrologic Assessment of Buenos Aires National Wildlife Refuge, Altar Valley, Southeastern Arizona
}

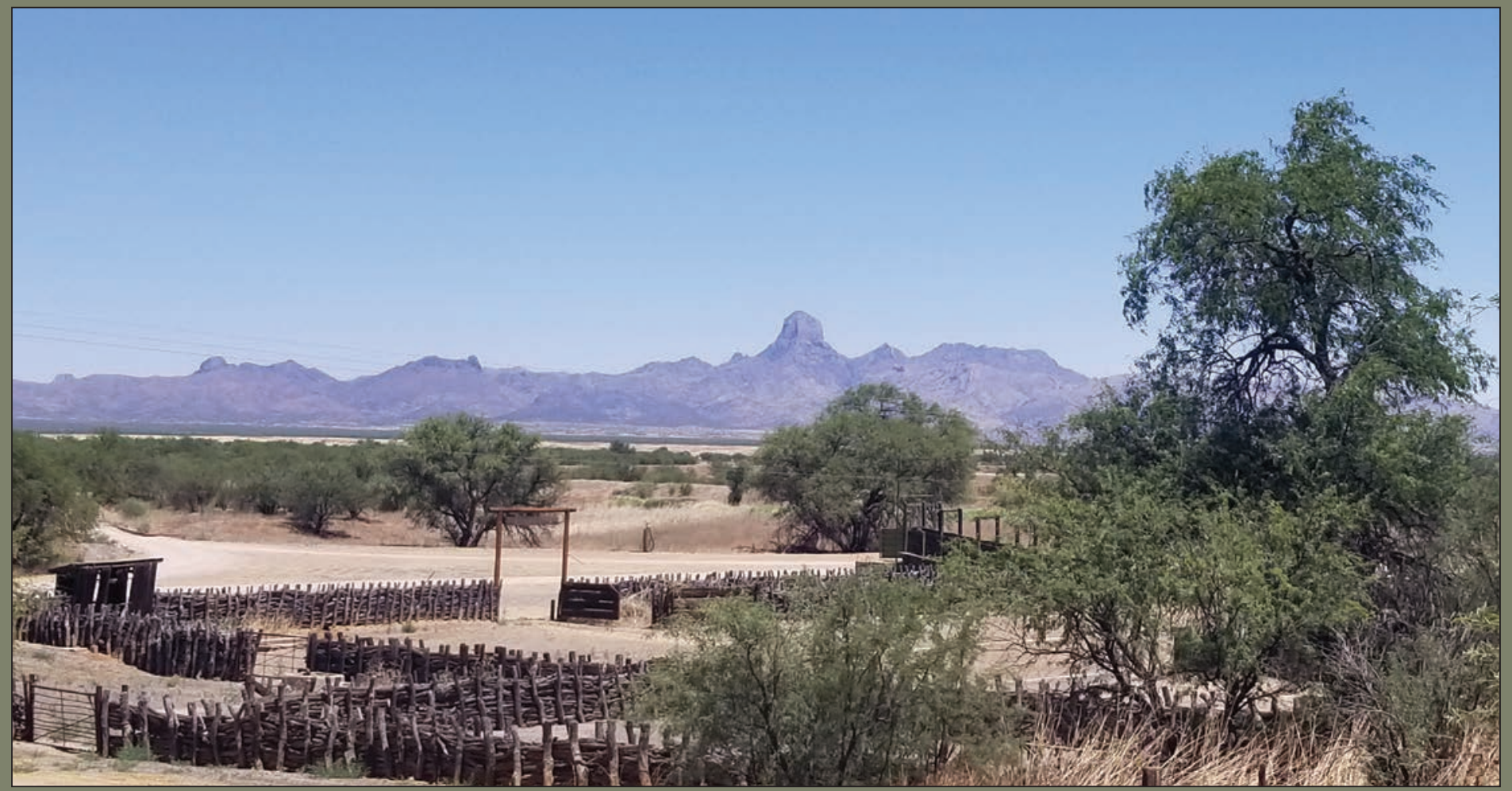

Scientific Investigations Report 2021-5050

U.S. Department of the Interior U.S. Geological Survey 
Cover. View to north-northwest toward Baboquivari Peak from corrals at Buenos Aires National Wildlife Refuge Headquarters, located at Buenos Aires Ranch, Ariz. Photograph by James B. Callegary, July 3, 2018. 


\section{Preliminary Geohydrologic Assessment of Buenos Aires National Wildlife Refuge, Altar Valley, Southeastern Arizona}

By Sandra J. Owen-Joyce, James B. Callegary, and Amy Elizabeth Rosebrough

Prepared in cooperation with the U.S. Fish and Wildlife Service

Scientific Investigations Report 2021-5050 


\section{U.S. Geological Survey, Reston, Virginia: 2021}

For more information on the USGS — the Federal source for science about the Earth, its natural and living resources, natural hazards, and the environment-visit https://www.usgs.gov or call 1-888-ASK-USGS.

For an overview of USGS information products, including maps, imagery, and publications, visit https://store.usgs.gov.

Any use of trade, firm, or product names is for descriptive purposes only and does not imply endorsement by the U.S. Government.

Although this information product, for the most part, is in the public domain, it also may contain copyrighted materials as noted in the text. Permission to reproduce copyrighted items must be secured from the copyright owner.

Suggested citation:

Owen-Joyce, S.J., Callegary, J.B., and Rosebrough, A.E., 2021, Preliminary geohydrologic assessment of Buenos Aires National Wildlife Refuge, Altar Valley, southeastern Arizona: U.S. Geological Survey Scientific Investigations Report 2021-5050, 29 p., https://doi.org/10.3133/sir20215050.

Associated data for this publication:

Owen-Joyce, S.J., 2021, Groundwater well data and annual groundwater pumpage data (1984 - 2019) in Altar Valley, Arizona: U.S. Geological Survey data release, https://doi.org/10.5066/P90ST80X.

ISSN 2328-0328 (online) 


\section{Acknowledgments}

This study was conducted with support from the U.S. Fish and Wildlife Service (USFWS) and the Transboundary Aquifer Assessment Program in the Water Mission Area of the U.S. Geological Survey (USGS).

The authors wish to extend thanks to Andrew Hautzinger and Joaquin Baca (both USFWS) for providing data and geographic information system (GIS) shapefiles of the Buenos Aires National Wildlife Refuge.

Thanks are also extended to Lisa Williams of the Arizona Department of Water Resources (ADWR) for a retrieval of the pumpage data for Avra-Altar Basin. 


\section{Contents}

Acknowledgments ........................................................................................................................

Abstract

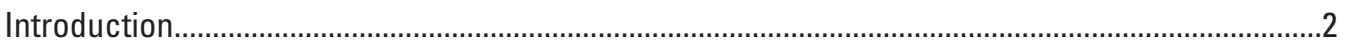

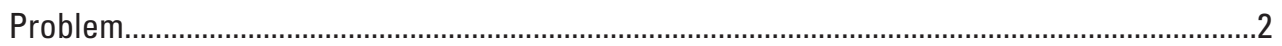

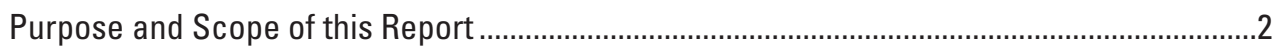

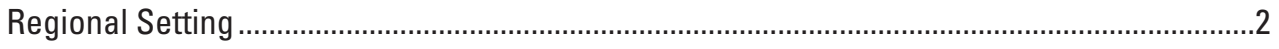

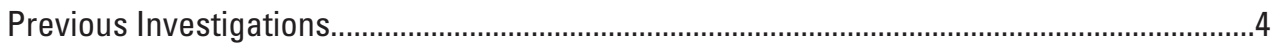

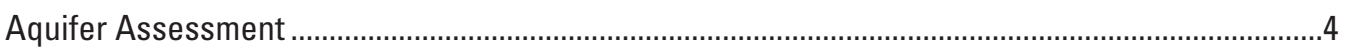

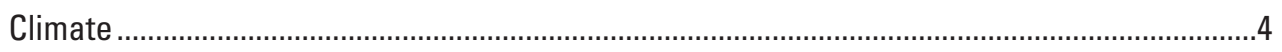

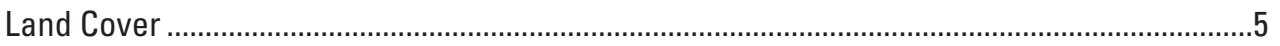

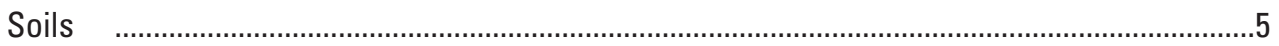

Geology

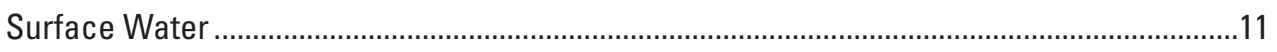

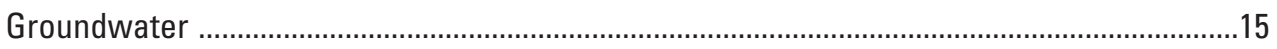

Altar Valley Precipitation-Groundwater Level Correlation ...........................................................17

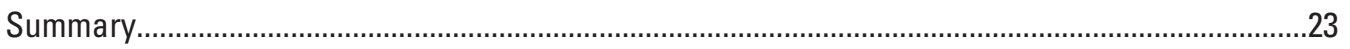

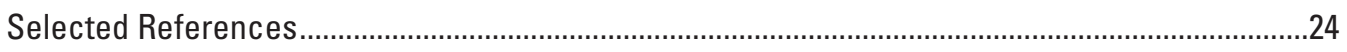

Appendix 1. Selected Well Data in the Altar Valley, Arizona, Groundwater Area ...........................28

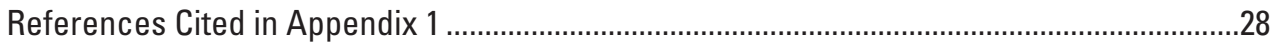

Appendix 2. Annual Groundwater Pumpage in Altar Valley, Arizona, Between 1984 and 2019......29

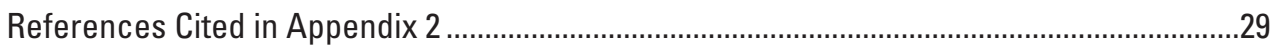

\section{Figures}

Index map showing well-numbering and -naming system used by the

U.S. Geological Survey in Arizona ..viii

1. Satellite-image base map showing Altar Valley groundwater area and Buenos Aires National Wildlife Refuge, Arizona, as well as locations of selected index wells, gages, weather stations, an oil test drill hole, and other geographic features mentioned in text

2. Satellite-image base map showing spatial distribution of land-cover classes in Altar Valley groundwater area and Buenos Aires National Wildlife Refuge, Arizona

3. Satellite-image base map showing distribution of soil units within Altar Valley groundwater area and Buenos Aires National Wildlife Refuge, Arizona ...

4. Satellite-image base map showing saturated vertical hydraulic conductivity of soil units in Altar Valley groundwater area and Buenos Aires National Wildlife Refuge, Arizona

5. Shaded-relief geologic map of Altar Valley groundwater area and Buenos Aires National Wildlife Refuge, Arizona; also shown are depth-to-bedrock contours, various well locations, and an oil test drill hole 
6. Graph showing annual streamflow at Altar Wash near Three Points and at Brawley Wash near Three Points , Arizona, from 1993 to 2018

7. Plots showing daily mean streamflow at Arivaca Wash near Arivaca, Arivaca Creek at Arivaca, and Arivaca Creek near Arivaca, Arizona, for variable periods of record.

8. Plot showing water levels from January 2019, showing groundwater gradient from south to north along center of Altar Valley, Arizona...

9. Graph showing comparison of annual pumpage from wells that pump more than 35 gallons per minute between northern and southern parts of Altar Valley, Arizona, between 1984 and 2019

10. Plot showing annual average precipitation and temperature in Altar Valley, Arizona, plotted as 3-year moving-average departure from 123-year median-precipitation and -temperature value

11. Plots showing depth to water for selected wells and average annual precipitation in southern part of Altar Valley, Arizona; precipitation plotted as 3-year movingaverage departure from 123-year median-precipitation values

12. Plots showing depth to water for selected wells and average annual precipitation in northern part of Altar Valley, Arizona; precipitation plotted as 3-year movingaverage departure from 123-year median-precipitation values

13. Plot of lag correlation analysis, showing unitless standardized residual values of precipitation, of groundwater levels at well in southern part of Altar Valley, Arizona, and groundwater levels lagged 17 years

14. Plot of lag correlation analysis, showing unitless standardized residual values of precipitation, of groundwater levels at well in northern part of Altar Valley, Arizona, and groundwater levels lagged 25 years

\section{Tables}

1. Monthly rainfall normals, from 1981 to 2010 , in Altar Valley, Arizona .................................5

2. Official Soils Series names and brief descriptions of soil units in Altar Valley groundwater area, Arizona

3. Mean monthly streamflow at gaging stations in Altar Valley, Arizona ............................11

4. Water-level-trend assessment of Altar Valley, Arizona, using the nonparametric Mann-Kendall statistic 


\section{Conversion Factors}

U.S. customary units to International System of Units

\begin{tabular}{|c|c|c|}
\hline Multiply & By & To obtain \\
\hline \multicolumn{3}{|c|}{ Length } \\
\hline inch (in.) & 2.54 & centimeter $(\mathrm{cm})$ \\
\hline inch (in.) & 25.4 & millimeter $(\mathrm{mm})$ \\
\hline inch (in.) & 25,400 & micrometer $(\mu \mathrm{m})$ \\
\hline foot $(\mathrm{ft})$ & 0.3048 & meter (m) \\
\hline mile (mi) & 1.609 & kilometer (km) \\
\hline \multicolumn{3}{|c|}{ Area } \\
\hline acre & 0.004047 & square kilometer $\left(\mathrm{km}^{2}\right)$ \\
\hline square mile $\left(\mathrm{mi}^{2}\right)$ & 2.590 & square kilometer $\left(\mathrm{km}^{2}\right)$ \\
\hline \multicolumn{3}{|c|}{ Flow rate } \\
\hline acre-foot per year (acre-ft/yr) & 1,233 & cubic meter per year $\left(\mathrm{m}^{3} / \mathrm{yr}\right)$ \\
\hline gallon per minute (gal/min) & 0.06309 & liter per second $(\mathrm{L} / \mathrm{s})$ \\
\hline \multicolumn{3}{|c|}{ Density } \\
\hline pound per cubic foot $\left(\mathrm{lb} / \mathrm{ft}^{3}\right)$ & 0.01602 & gram per cubic centimeter $\left(\mathrm{g} / \mathrm{cm}^{3}\right)$ \\
\hline \multicolumn{3}{|c|}{ Hydraulic conductivity } \\
\hline foot per day (ft/d) & 0.3048 & meter per day $(\mathrm{m} / \mathrm{d})$ \\
\hline inch per second (in/s) & 25,400 & micrometer per second $(\mu \mathrm{m} / \mathrm{s})$ \\
\hline
\end{tabular}

International System of Units to U.S. customary units

\begin{tabular}{ccc}
\hline \multicolumn{1}{c}{ Multiply } & By & To obtain \\
\hline \multicolumn{2}{c}{ Density } & \\
\hline gram per cubic centimeter $\left(\mathrm{g} / \mathrm{cm}^{3}\right)$ & 62.4220 & pound per cubic foot $\left(\mathrm{lb} / \mathrm{ft}^{3}\right)$ \\
\hline & Hydraulic conductivity & \\
\hline micrometer per second $(\mu \mathrm{m} / \mathrm{s})$ & $3.28084 \mathrm{e}-6$ & foot per day $(\mathrm{ft} / \mathrm{d})$ \\
\hline
\end{tabular}

Temperature in degrees Celsius $\left({ }^{\circ} \mathrm{C}\right)$ may be converted to degrees Fahrenheit $\left({ }^{\circ} \mathrm{F}\right)$ as follows:

$$
{ }^{\circ} \mathrm{F}=\left(1.8 \times{ }^{\circ} \mathrm{C}\right)+32 .
$$

Temperature in degrees Fahrenheit $\left({ }^{\circ} \mathrm{F}\right)$ may be converted to degrees Celsius $\left({ }^{\circ} \mathrm{C}\right)$ as as follows:

$$
{ }^{\circ} \mathrm{C}=\left({ }^{\circ} \mathrm{F}-32\right) / 1.8 \text {. }
$$

\section{Datum}

Vertical coordinate information is referenced to the North American Vertical Datum of 1988 (NAVD 88).

Horizontal coordinate information is referenced to the North American Datum of 1983 (NAD 83).

Altitude, as used in this report, refers to distance above the vertical datum. 


\section{Abbreviations}

$\begin{array}{ll}\text { ADWR } & \text { Arizona Department of Water Resources } \\ \text { AMA } & \text { Active Management Area } \\ \text { BANWR } & \text { Buenos Aires National Wildlife Refuge } \\ \text { C.E. } & \text { Common Era } \\ \text { CBP } & \text { U.S. Customs and Border Protection } \\ \text { CONAGUA } & \text { Comisión Nacional del Agua } \\ \text { ET } & \text { evapotranspiration } \\ \text { GIS } & \text { geographic information system } \\ \text { K-Ar } & \text { potassium-argon } \\ \text { KV } & \text { vertical hydraulic conductivity } \\ \text { ka } & \text { thousands of years ago } \\ \text { Ma } & \text { millions of years ago } \\ \text { min } & \text { minute } \\ \text { NASA } & \text { National Aeronautics and Space Administration } \\ \text { NLCD } & \text { National Land Cover Database } \\ \text { NOAA } & \text { National Oceanic and Atmospheric Administration } \\ \text { NWIS } & \text { National Water Information System } \\ \text { NRCS } & \text { Natural Resources Conservation Service } \\ \text { PRISM } & \text { Parameter-elevation Relationships on Independent Slopes Model } \\ r & \text { correlation coefficient } \\ \text { Rb-Sr } & \text { rubidium-strontium } \\ \text { S } & \text { second } \\ \text { SSD USDA } & \text { Soil Science Division Staff, U.S. Department of Agriculture } \\ \text { SSS USDA } & \text { Soil Survey Staff, U.S. Department of Agriculture } \\ \text { SSURGO } & \text { Soil Survey geographic database } \\ \text { STATSGO } & \text { State soil geographic database } \\ \text { TAMA } & \text { Tucson Active Management Area } \\ \text { TAAP } & \text { Transboundary Aquifer Assessment Program } \\ \text { USDA } & \text { U.S. Department of Agriculture } \\ \text { USDA NRCS } & \text { U.S. Department of Agriculture, Natural Resources Conservation Service } \\ \text { USFWS } & \text { U.S. Fish and Wildlife Service } \\ \text { USGS } & \text { U.S. Geological Survey } \\ \text { yr } & \text { year } \\ & \end{array}$




\section{Supplemental Information}

WELL (D-19-09) 15adc
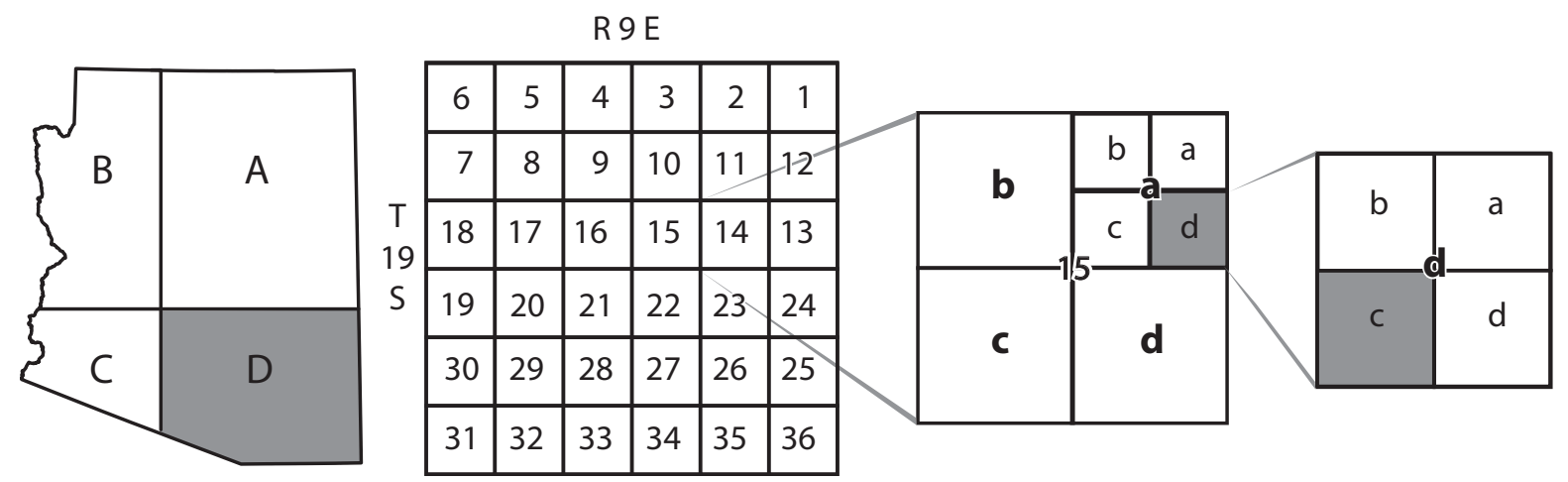

Quadrant D, Township 19 South, Range 09 East, section 15, quarter section a, quarter section $d$, quarter section $c$

The well numbers used by the U.S. Geological Survey in Arizona are in accordance with the Bureau of Land Management's system of land subdivision. The land survey in Arizona is based on the Gila and Salt River meridian and base line, which divide the State into four quadrants and are designated by capital letters $A, B, C$, and $D$ in a counterclockwise direction beginning in the northeast quarter. The first digit of a well number indicates the township, the second the range, and the third the section in which the well is situated. The lowercase letters $a, b, c$, and $d$ after the section number indicate the well location within the section. The first letter denotes a particular 160 -acre tract, the second the 40 -acre tract, and the third the 10 -acre tract. These letters also are assigned in a counterclockwise direction beginning in the northeast quarter. If the location is known within the 10-acre tract, three lowercase letters are shown in the well number. Where more than one well is within a 10-acre tract, consecutive numbers beginning with 1 are added as suffixes. In the example shown, well number (D-19-09)15adc designates the well as being in the SW1/4, SE1/4, NE1/4, section 15, Township 19 South, and Range 09 East. 


\title{
Preliminary Geohydrologic Assessment of Buenos Aires National Wildlife Refuge, Altar Valley, Southeastern Arizona
}

\author{
By Sandra J. Owen-Joyce, ${ }^{1}$ James B. Callegary, and Amy Elizabeth Rosebrough ${ }^{2}$
}

\section{Abstract}

The Buenos Aires National Wildlife Refuge is located in the southern part of Altar Valley, southwest of Tucson in southeastern Arizona. The primary water-supply well at the Buenos Aires National Wildlife Refuge has experienced a two-decade decrease in groundwater levels in the well, as have other wells in the southern part of Altar Valley. In part to understand this trend, a study was undertaken by the U.S. Geological Survey, in cooperation with the U.S. Fish and Wildlife Service, to summarize what is known about the geohydrologic system on the refuge and analyze groundwaterlevel trends and precipitation-groundwater correlations. In addition, available data were compiled where possible on the climate, land cover, soils, geology, and hydrology to provide a foundation for future modeling of the system.

Altar Valley is a sedimentary basin bounded by a mixture of Paleozoic to Tertiary sedimentary, volcanic, granitic, and metamorphic rocks. The valley fill is undifferentiated Tertiary to Quaternary sediments underlain by middle Miocene to Pliocene rocks that consist of moderately to strongly consolidated conglomerate and sandstone. Surface water, when present in the predominantly ephemeral streams of the valley, flows from south to north. Arivaca Creek has a cienega (or wetland) where groundwater surfaces before it flows as a short perennial reach out of Arivaca Basin. Groundwater maps compiled between 1934 and 2016 showed groundwater flowing from south to north. Before the 1980s, temporal patterns of groundwater levels in wells in Altar Valley varied substantially from one well to another. In the mid1980s, comparatively high levels of precipitation occurred: the 1980 s median value was 15.3 inches (in.), whereas the median for the period of record was 13.2 in. In addition, apparently corresponding groundwater level increases were seen in nearly all wells studied. After this initial increase, two different groundwater-level trends began to be observed in two spatially distinct sets of wells: in the northern part, groundwater levels were relatively steady, whereas in the southern part, groundwater levels declined from 10 to 20 feet (ft) between 1990 and 2019. Annual groundwater pumpage

${ }^{1}$ U.S. Geological Survey.

${ }^{2}$ University of Arizona. declined substantially in the northern part of the valley beginning in the early 1980s, but it began to increase again in the 1990s. Pumpage in the southern part has remained low and relatively steady compared to the northern part. Although the precise reasons for the declining groundwater levels in the southern part remain unclear, groundwater levels may be affected by factors such as climate cycles, long-term drought, and temperature-induced declines in recharge, resulting in increased evapotranspiration.

Preliminary analyses of two wells, one selected from each part of the valley, using linear regression and lag correlation to investigate correlation between annual precipitation and groundwater levels, showed a maximum correlation at a lag of about 17 years (yr) in the southern part of the valley and about $25 \mathrm{yr}$ in the northern part, indicating that, although variable sources and traveltimes of recharged water may be needed to propagate to each location, the strongest correlation at each well is with precipitation that was recharged 17 and $25 \mathrm{yr}$ prior to the groundwater response in that well. Assuming a constant flow of groundwater from the southern to the northern part of the valley, a decrease in recharge is expected to lead to a decrease in aquifer storage. As to the comparatively stable groundwater levels in the northern part, pumpage is still only about one-half what it was in the early 1980s, even though pumpage has increased there since the 1990s. Water levels in most wells in the northern part were drawn down prior to the decrease in pumping in the early 1980s, possibly owing to a combination of pumping and the nearly 20-year midcentury drought that occurred between 1940 and 1960. Water levels were in the process of recovering when the increase in pumping occurred in the 1990s. Because the water levels were recovering (increasing) instead of remaining static, the increased pumping may have only limited the recovery rather than causing a decrease in water levels, as a new quasi-equilibrium state may have been reached. Additional possible causes for the stable groundwater levels include (1) upgradient aquifer transmissivity that was high enough to offset pumping, (2) a low-permeability barrier, such as bedrock or clay, at the north end of the valley that caused groundwater pooling, (3) higher lateral inflow of groundwater in the northern part of the valley, (4) a delay in the effect of storage declines propagating from the south, or (5) some combination thereof. 


\section{Introduction}

In 1985, the Buenos Aires National Wildlife Refuge (BANWR) was established on 117,464 acres in southeastern Arizona (fig. 1). BANWR is managed by the U.S. Fish and Wildlife Service (USFWS) to benefit threatened and endangered species, as well as to provide public activities such as wildlife viewing and hunting. The refuge, which preserves multiple biotic communities that range from semidesert grassland to riparian woodlands, supports conservation efforts for the endangered masked bobwhite quail (Colinus virginianus ridgwayi Brewster) along with other federally protected species such as the Chiricahua leopard frog (Lithobates chiricahuensis), Pima pineapple cactus (Coryphantha scheeri var. robustispina), yellow-billed cuckoo (Coccyzus americanus), and Arizona jaguar (Panthera onca arizonensis). The southern border of BANWR is part of the 1,900-mile (mi) U.S.-Mexico border.

Water for refuge operations, including potable water use for staff and visitors, comes from wells drilled to depths of over 400 feet (ft). A primary water-supply well at BANWR (D-21-08 27ADA1) is permitted by the State of Arizona for a total annual withdrawal of 6 acre-feet per year (acre-ft/yr); however, about $1.5 \mathrm{acre}-\mathrm{ft} / \mathrm{yr}$ is currently pumped (fig. 1, well 27ADA1). USFWS managers noted downward groundwatertable trends in their supply wells, beginning in the 1990s; however, both the hydrogeologic system that underlies BANWR and the root cause of downward groundwater-table trends were poorly understood. A study was undertaken by the U.S. Geological Survey (USGS), in cooperation with the USFWS, to summarize what is known about the hydrologic system on the BANWR and Altar Valley. This present (2020) study, which includes the compiled data, and a companion study, which uses modeling for stakeholder engagement, are together serving as a pilot for the Transboundary Aquifer Assessment Program (TAAP), testing the feasibility of a relatively simple approach for basic aquifer assessment that could potentially be applied to other relatively uncharacterized aquifers along the U.S.-Mexico border.

\section{Problem}

U.S. Customs and Border Protection (CBP) recently requested from managers at BANWR the use of some of the groundwater from the BANWR supply well for road construction and maintenance projects to aid in security operations along the U.S.-Mexico border. Considering the two-decade decrease in the groundwater level at the well and the increasing regional demands of groundwater resources in southern Arizona, managers at BANWR needed to make a shortterm, hydrologically informed decision on the request from CBP. BANWR resource managers also need an improved, longer term conceptual understanding of the hydrogeologic framework of the groundwater resources at the refuge. This improved understanding may allow better long-term management of BANWR water resources to address both the conservation mission of the refuge and security needs of the Nation along the U.S.-Mexico border.
The purpose of this study was to assist the USFWS in understanding groundwater resources at BANWR by conducting an updated assessment of the geohydrologic system, as well as to investigate groundwater conditions related to the declining groundwater levels in the BANWR wells. This study involved compiling and analyzing existing data for the study area. The study also supports the goals of the USGS' TAAP, and it, along with a companion modeling study, served as a pilot study for testing the feasibility of a relatively simple approach for basic aquifer assessment and stakeholder engagement that could potentially be applied to other relatively uncharacterized aquifers along the U.S.-Mexico border.

\section{Purpose and Scope of this Report}

The purpose of this report is to provide a preliminary geohydrologic characterization of BANWR in Altar Valley. Specifically, this report (1) summarizes previous work, (2) describes existing data, (3) provides updates on groundwater data in the National Water Information System (NWIS) database for BANWR and surrounding areas, and (4) describes potential correlation between climate and groundwater levels in the Altar Valley.

\section{Regional Setting}

Altar Valley extends from Mexico northward across the U.S.-Mexico border into southeastern Arizona, to the south end of Avra Valley near Three Points and Route 86 (fig. 1). BANWR lies within the south-central part of Altar Valley, from the U.S.-Mexico border north to near the intersection of Brown Wash and Altar Wash, and it extends up Brown Canyon on the west and up Arivaca Creek into the Arivaca Basin on the east. About 3-5 miles north of the U.S.-Mexico border is a drainage divide where the area to the north is drained by many ephemeral streams that flow into Altar and Brawley Washes. The valley is bounded on the west by the Pozo Verde, Baboquivari, Quinlan, and Coyote Mountains and on the east by the San Luis, Las Guijas, Cerro Colorado, and Sierrita Mountains.

Altar Valley originally was part of O'odham inhabited lands. Although today (2020) it is not formally part of the Tohono O'odham Nation, the valley is still sacred to the O'odham. Don Pedro Aguirre, who arrived in the valley around 1870, established the Buenos Aires Ranch and constructed the earthen impoundment Aguirre Lake in the late 1800s. Buenos Aires Ranch continued under various ownerships until it was acquired by the USFWS and the BANWR was created; the BANWR is headquartered at the ranch (Fuller, 2016). Altar Valley remained largely undeveloped except for ranches where groundwater was predominantly used for domestic- and stock-water purposes. A small amount of land was developed for agriculture south of Three Points in the 1950s. Most agricultural development began in the 1950s north of Altar Valley and also north of Three Points in Avra Valley, and, as early as 1965, it was reported that groundwater levels were lowering in Avra Valley (White and others, 1966). Annual groundwater pumpage 


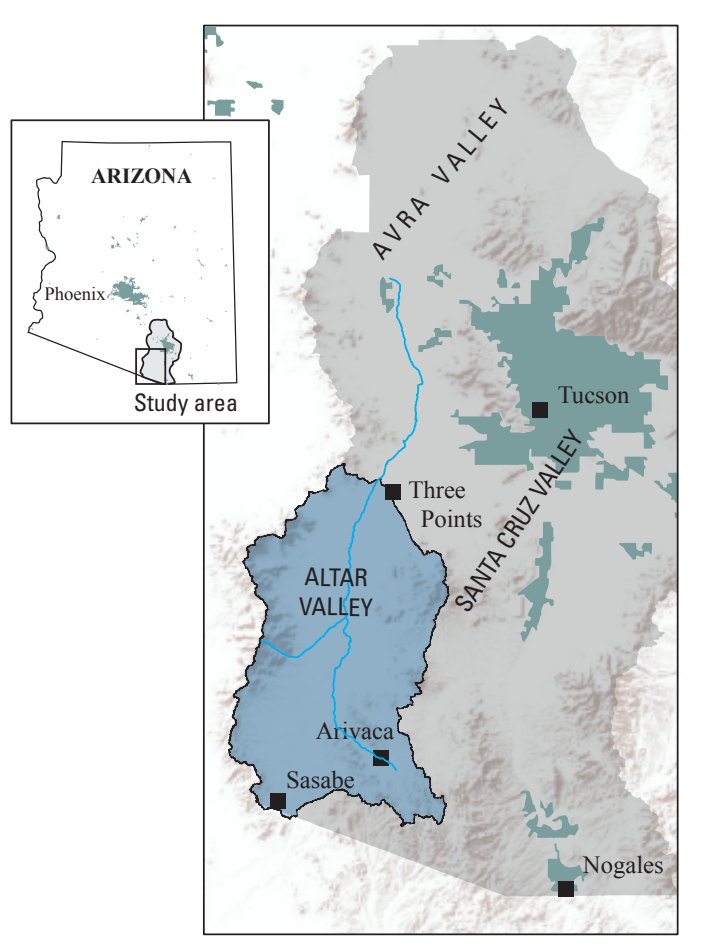

EXPLANATION

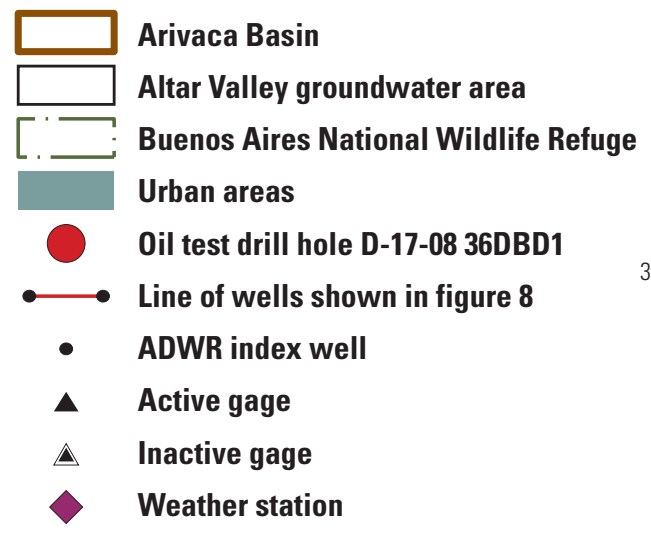

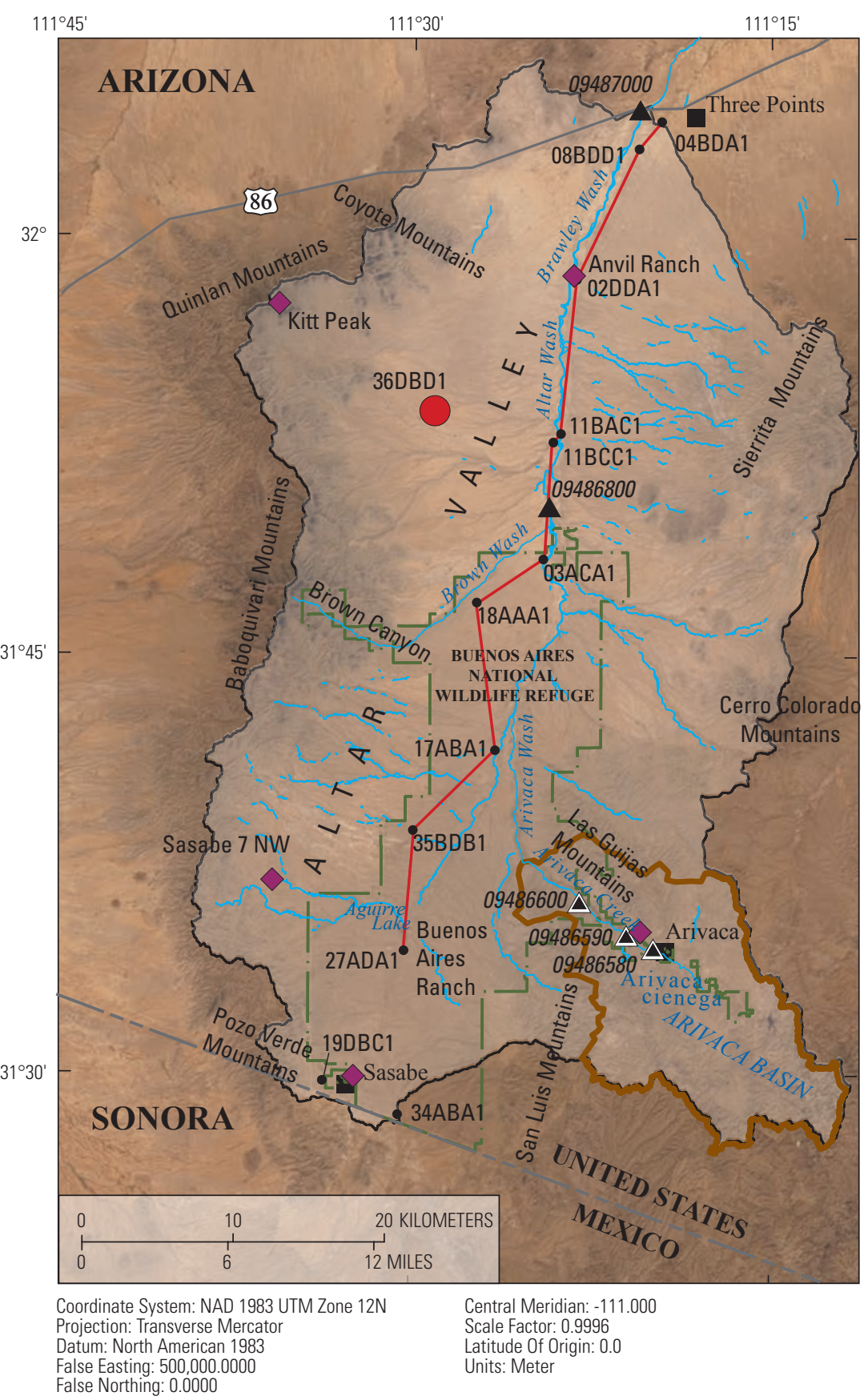

Figure 1. Satellite-image base map showing Altar Valley groundwater area (as delineated by U.S. Geological Survey [USGS]) and Buenos Aires National Wildlife Refuge (BANWR), Arizona, as well as locations of selected index wells, gages, weather stations, an oil test drill hole, and other geographic features mentioned in text. Locations of index wells, gages, and oil test drill hole from National Water Information System (USGS, 2020); weather-station locations from Western Regional Climate Center (2021). Boundary of Altar Valley groundwater area from Wilson (1991); BANWR boundary from U.S. Fish and Wildlife Service. Satellite-image base map from Esri; urban areas, drainage features, national boundary, and road from USGS' The National Map (https://viewer.nationalmap.gov).

was compiled by USGS (by groundwater areas delineated by USGS) through 1983; since then, pumpage has been compiled by the Arizona Department of Water Resources (ADWR). Prior to 1983, Altar Valley pumpage estimates were included with those for Avra Valley; in 1983, however, the estimated annual groundwater pumpage in Altar Valley became important enough to be listed separately (Wilson, 1991).

As late as 2019, Altar Valley remained largely undeveloped except for some subdivisions that have replaced agricultural lands south of Route 86 near Three Points. Ownership of some older withdrawal wells has been transferred to the City of Tucson, and they have been converted to monitoring wells. 
Preliminary Geohydrologic Assessment of Buenos Aires National Wildlife Refuge, Altar Valley, Southeastern Arizona

\section{Previous Investigations}

The Spanish traditionally referred to the Tohono O'odham people of the Sonoran Desert as "Papago," and, in historical publications, the Avra and Altar Valleys generally were referred to as part of "Papago country." The "Papago" name has since been rejected and replaced by Tohono O'odham. In later publications, Altar and Avra Valleys were included with the Santa Cruz Valley. Currently (2020), Altar, Avra, and Santa Cruz Valleys are part of the Tucson Active Management Area (TAMA). Initial descriptions of the geography, geology, and water resources of Altar Valley (as part of "Papago country") can be found in Bryan (1925). A later report (Andrews, 1937) included more detail on the geography, geology, groundwater conditions, groundwater development, and water quality of the Avra and Altar Valleys, and it also included a water-table-contour map that showed 1934 conditions. Subsequent reports on the groundwater resources of the Santa Cruz Basin had sparse groundwater data because of a lack of development; therefore, Altar Valley was included as part of Avra Valley (Turner and others, 1943; Turner, 1947). A study of the hydrologic characteristics of the aquifer and availability by White and others (1966) included a water-level-contour map that showed 1965 conditions.

In 1980, Arizona passed the Arizona Groundwater Management Act, which mandated groundwater conservation from agricultural, industrial, and municipal sectors and increased regulation and monitoring, in order to diminish reliance on groundwater enough that recharge and extraction be roughly in balance by 2025. The Arizona Groundwater Management Act created Active Management Areas (AMAs) where groundwater levels are monitored and documented by ADWR. Avra and Altar Valleys were included in the TAMA on June 12, 1980 (Reeter and Cady, 1982). Reports on groundwater conditions in the AMAs, which include water-level maps, well hydrographs, and water-quality data, are available for the Avra and Altar Valleys for 1981 (Reeter and Cady, 1982), the Santa Cruz AMA for 1995 (Hammett and Sicard, 1995), statewide for 1980 to 2000 (Corkhill, 2012), and statewide for 1993 to 2013 (Davis and others, 2014), as well as statewide groundwater-level changes for 1996 to 2016 (Arizona Department of Water Resources [ADWR], 2017).

BANWR extends to the east, upstream along Arivaca Creek and into the Arivaca Basin. A comprehensive hydrogeologic assessment of the isolated aquifer system in the Arivaca Basin (Pima Association of Governments Watershed Planning, 2006; see also, Schorr, 2005) focused on the aquifer characteristics, groundwater pumping, recharge, and riparian vegetation and included maps of simplified geology, interpolated depth to bedrock and alluvium thickness, and simulated groundwater levels. Model results indicated that groundwater levels have declined throughout the Arivaca Basin since the 1970s and that streamflow in Arivaca Creek and water levels in the cienega are vulnerable to groundwater pumping, water diversions, and drought (Schorr, 2005; Pima Association of Governments Watershed Planning, 2006). Most of Arivaca Creek and the entire cienega are included within BANWR.

\section{Aquifer Assessment}

An aquifer is a body of porous rock, sediment, or fractured rock that is saturated with groundwater and permeable enough to yield economically viable quantities of water. To understand an aquifer system, groundwater is traced from its source to where it exits the system. The main source is precipitation that falls on the land surface, where some is used by vegetation, some runs off into streams, and some seeps through soils or streambeds to recharge the aquifer. Water in the aquifer flows downgradient where it may resurface through springs or is intercepted by wells. The speed of groundwater flow is dependent on the permeability of the aquifer materials. Groundwater flows quicker through the interconnected cracks or larger pore spaces in materials such as sand or gravel than it does through materials that have smaller pore spaces such as clay and shale. Computer models are commonly used to simulate and evaluate groundwater-flow systems. To better understand the Altar Valley aquifer system, available data were compiled on climate, land cover, soils, geology, and hydrology to be used for future modeling of the system.

\section{Climate}

The climate of south-central Arizona is semiarid. Although extreme variability in precipitation is normal, currently (2020) Arizona is in the 21st year (yr) of a longterm drought (Arizona State Climate Office, 2019). Annual rainfall measured at National Oceanic and Atmospheric Administration (NOAA) cooperative stations in Altar Valley varies from 11.41 inches (in.) in the valley, to $23.54 \mathrm{in}$. in the mountains to the west, and to 18.69 in. in the Arivaca Basin in the mountains to the east. Most of the annual rainfall occurs during the summer monsoonal rains (table 1). Predictions issued in May 2020 for July-December 2020 showed a more than 50 percent chance for above normal temperatures for Anvil Ranch (National Weather Service Forecast Office, 2020a), Sasabe (National Weather Service Forecast Office, 2020c), and Kitt Peak (National Weather Service Forecast Office, 2020b). This prediction was born out after a temperature assessment showed that July through September 2020 was the hottest on record for south-central Arizona (West Wide Drought Tracker, 2020a). This was accompanied by record-low precipitation for the same period (West Wide Drought Tracker, 2020b).

Williams and others (2020) used hydrological modeling and a 1,200-yr tree-ring reconstruction of summer soil moisture to determine that the 2000-2018 drought in southwestern North America was the second driest 19 -yr period since 800 C.E.; the driest was a late-1500s megadrought, a prolonged drought that lasted two decades or longer. Estimates from 31 climate models that included evapotranspiration (ET) suppression by elevated atmospheric carbon dioxide $\left(\mathrm{CO}_{2}\right)$ conservatively indicate that 30 percent of the 2000-2018 drought severity is accounted for by anthropogenic influences on temperature, relative humidity, and precipitation. These factors had the effect of converting 
Table 1. Monthly rainfall normals, from 1981 to 2010, in Altar Valley, Arizona.

[Data from National Weather Service (2019). See figure 1 for locations. Abbreviation: in., inches]

\begin{tabular}{|c|c|c|c|c|c|c|c|c|c|c|c|c|c|}
\hline \multirow{2}{*}{ Station name } & \multicolumn{13}{|c|}{ Monthly rainfall normal amount (in.) } \\
\hline & Jan & Feb & Mar & Apr & May & Jun & Jul & Aug & Sep & Oct & Nov & Dec & Total \\
\hline Anvil Ranch & 0.8 & 0.73 & 0.61 & 0.3 & 0.24 & 0.23 & 2.62 & 2.48 & 1.3 & 0.7 & 0.5 & 0.9 & 11.41 \\
\hline Arivaca & 1.3 & 1.34 & 1.14 & 0.52 & 0.28 & 0.45 & 4.15 & 4.25 & 1.71 & 1.18 & 0.8 & 1.57 & 18.69 \\
\hline Kitt Peak & 1.79 & 1.73 & 1.75 & 0.41 & 0.49 & 0.43 & 4.91 & 4.91 & 2.35 & 1.29 & 1.03 & 2.45 & 23.54 \\
\hline Sasabe & 1.25 & 1.31 & 1.05 & 0.57 & 0.18 & 0.04 & 3.41 & 3.32 & 1.85 & 0.9 & 0.64 & 1.92 & 16.76 \\
\hline Sasabe $7 \mathrm{NW}$ & 1.33 & 1.6 & 1.47 & 0.65 & 0.23 & 0.34 & 3.65 & 3.98 & 1.28 & 1.08 & 0.77 & 1.91 & 18.29 \\
\hline
\end{tabular}

what would have been the 11 th most severe drought into the most severe megadrought since 800 C.E. in southwestern North America.

\section{Land Cover}

Land cover was assessed using the 2016 National Land Cover Database (NLCD) (Yang and others, 2018). The study area is about 839 square miles $\left(\mathrm{mi}^{2}\right)$. Land cover is dominated by shrub/scrub $\left(648 \mathrm{mi}^{2}\right)$ and grassland/herbaceous $\left(171 \mathrm{mi}^{2}\right)$ land-cover classes (fig. 2). Smaller areal coverages are ascribed to evergreen forest $\left(12 \mathrm{mi}^{2}\right)$, developed open space $\left(6 \mathrm{mi}^{2}\right)$, and both emergent herbaceous wetlands and woody wetlands (combined, $2 \mathrm{mi}^{2}$ ). Developed open space includes vegetation intentionally grown and managed for recreation, erosion control, or aesthetics.

An understanding of spatial and temporal variability in land cover (vegetation type and developed land) is important for understanding hydrologic processes. Land cover affects the timing, magnitude, and spatial distribution of fluxes such as runoff, infiltration, and ET. Estimates of the runoff and infiltration can be obtained using rainfall-runoff and coupled groundwater-surface water models, which require estimates of ET and other land-cover-linked parameters.

Several estimates of land-cover-derived ET in southern Arizona are available or have been published. For example, daily ET measurements have been reported since 2003 for a site near Sahuarita, Ariz., which is in the adjacent valley east of the study area (Arizona Meteorological Network, 2020). In addition, Tillman and others (2011) and Glenn and others (2015) published regional estimates of ET that combined measurements from National Aeronautics and Space Administration's (NASA's) Terra satellite with Eddy covariance and Bowen ratio moisture-flux towers. The ET rates published in these sources are readily adapted to the land-cover classes mapped in the NLCD (Yang and others, 2018).

\section{Soils}

Polygons that represent soil types were extracted from the State Soil Geographic (STATSGO) Database for Arizona (Soil Survey Staff, U.S. Department of Agriculture [SSS USDA], 2019c). Hydrologic information for each soil polygon (map unit) was derived from official soil series descriptions (SSS USDA, 2019a). Saturated vertical hydraulic conductivity $(K v)$ was qualitatively estimated using a combination of (1) the proportional coverage of individual soil series, (2) the permeability classification of the soil (U.S. Department of Agriculture, Natural Resources Conservation Service [USDA NRCS], 2019), (3) the estimated depth to bedrock, and (4) the presence and thickness of petrocalcic (hardpan) or argillic (clay) horizons. Note that the term "bedrock" as used in soil survey refers to continuous, coherent (consolidated) rock; it can be a physical barrier within the soil that limits rooting depth, or it can be the immediate parent-material source for residual soils (Soil Science Division Staff, U.S. Department of Agriculture [SSD USDA], 2017). Each soil map unit within the study area is composed of a combination of two to five soil series, and each has different proportions of areal coverage. Differences in physical and hydraulic properties among the soil series can be substantial. The relative proportion of areal coverage of each soil series in the soil map unit was used quantitatively in the $K v$ estimate. $K v$ values for individual soil series were derived from the National Soil Survey Handbook (USDA NRCS, 2019). If bedrock was present within $30 \mathrm{in}$. of the surface, $K v$ was classified as low (that is, less than 0.30 micrometer per second $[\mu \mathrm{m} / \mathrm{s}])$. The presence and thickness of petrocalcic and argillic horizons were also accounted for in the classification.

Soil classifications in the United States are available at different scales through the Natural Resource Conservation Service (SSS USDA, 2019c). For hydrologic assessments at the scale of the present study, the coarser scale of STATSGO is appropriate. The spatial distribution of the 12 soil map units in the study area (fig. 3; table 2) is determined by official soil surveys. The 12 soil units are related, in part, to geology, particle-size distribution, geomorphic setting, precipitation, and elevation: for example, unit $\mathbf{3 0 3}$ is associated with Altar and Brawley Washes, which are the main streams in Altar Valley; unit $\mathbf{3 2 6}$ is associated with uplands in the southern part of the valley; and unit $\$ 329$ is associated with the mountain ranges that border the valley.

$K v$ generally follows geomorphic position: higher values are associated with uplands, streams, and floodplains, and lower values are associated with the mountains where depth to bedrock is frequently less than 30 in. (fig. 4). Despite the fact that soil properties, and therefore $K v$, vary on much smaller 

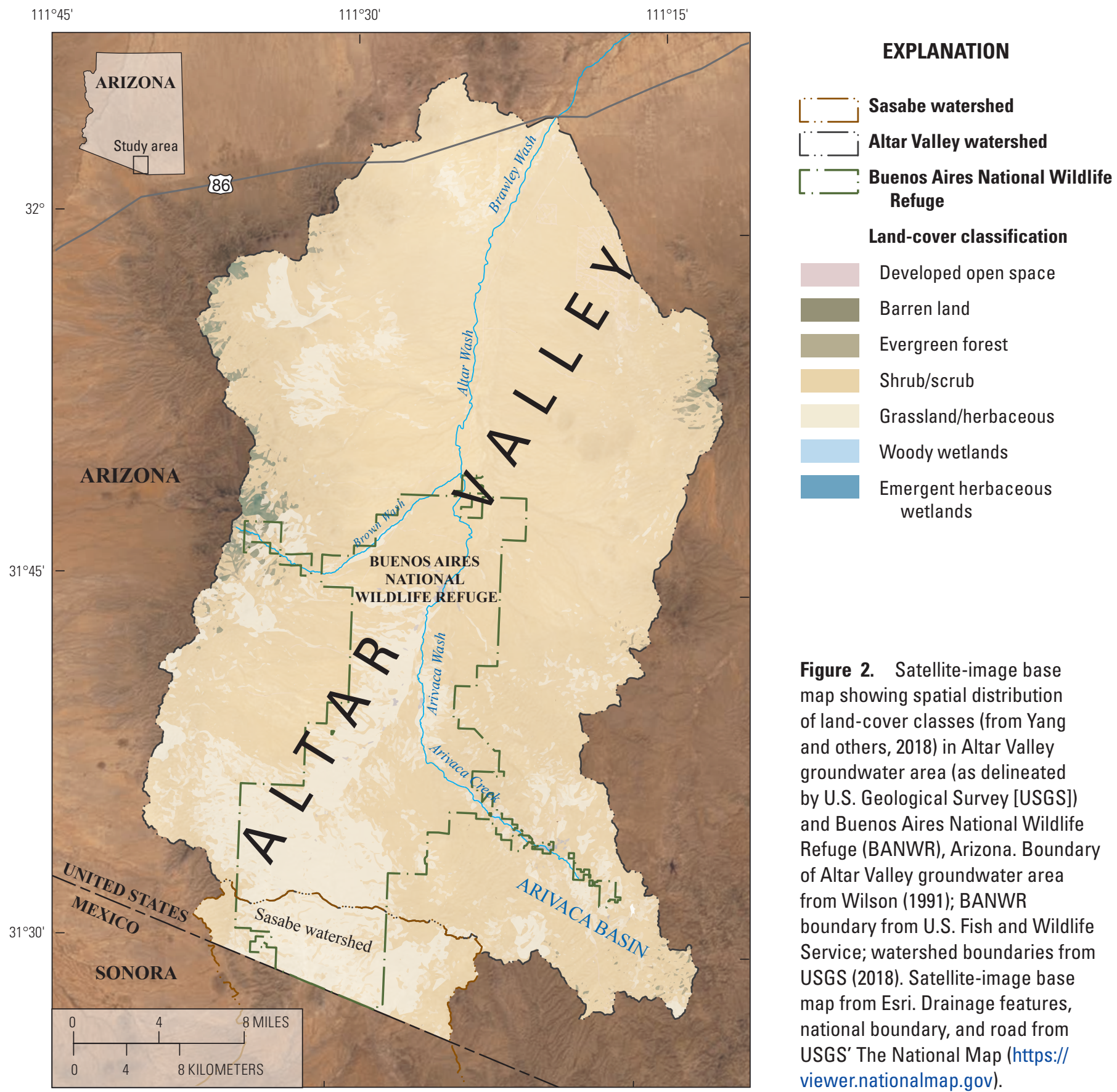

Figure 2. Satellite-image base map showing spatial distribution of land-cover classes (from Yang and others, 2018) in Altar Valley groundwater area (as delineated by U.S. Geological Survey [USGS]) and Buenos Aires National Wildlife Refuge (BANWR), Arizona. Boundary of Altar Valley groundwater area from Wilson (1991); BANWR boundary from U.S. Fish and Wildlife Service; watershed boundaries from USGS (2018). Satellite-image base map from Esri. Drainage features, national boundary, and road from USGS' The National Map (https:// viewer.nationalmap.gov).

scales than that of the soil map unit, STATSGO soil map units, if consonant with study objectives, would be appropriate for groundwater modeling on the scale of the study area. The scale can be modified either by adjusting $K v$ values and polygon dimensions or by using a higher resolution dataset such as SSURGO (SSS USDA, 2019b).

\section{Geology}

Altar Valley, which is located within the Basin and Range physiographic province of North America, is a basin that contains unconsolidated, low-density, relatively permeable sedimentary materials that yield water to wells. In Altar Valley, the basin-fill sediments include geologic sedimentary rocks and deposits that are of Tertiary (for example, units Tsm, Tsy), Pliocene to Pleistocene (unit QTo), and Quaternary (units $\mathrm{Qr}, \mathrm{Q}$ ) ages. The basin is bounded by bedrock (that is, consolidated material) that crops out in the surrounding mountains and hills (fig. 5). The bedrock is a mixture of sedimentary (units $\mathrm{P}$, Jsv, KJs), volcanic (units Jv, TKv, $\mathrm{Ti}, \mathrm{Tv}, \mathrm{Tb}$ ), and granitic rocks (units Jkg, TKg, TKgm), depending on location (Richard and others, 2007), and it generally has low groundwater storage and poor primary porosity and permeability. The bedrock can yield water to wells where water-bearing discontinuities such as fractures, joints, and faults exist. Little was known about the depth of the basin in studies before 1980 because of a lack of well data, particularly for wells deep enough to penetrate bedrock, 


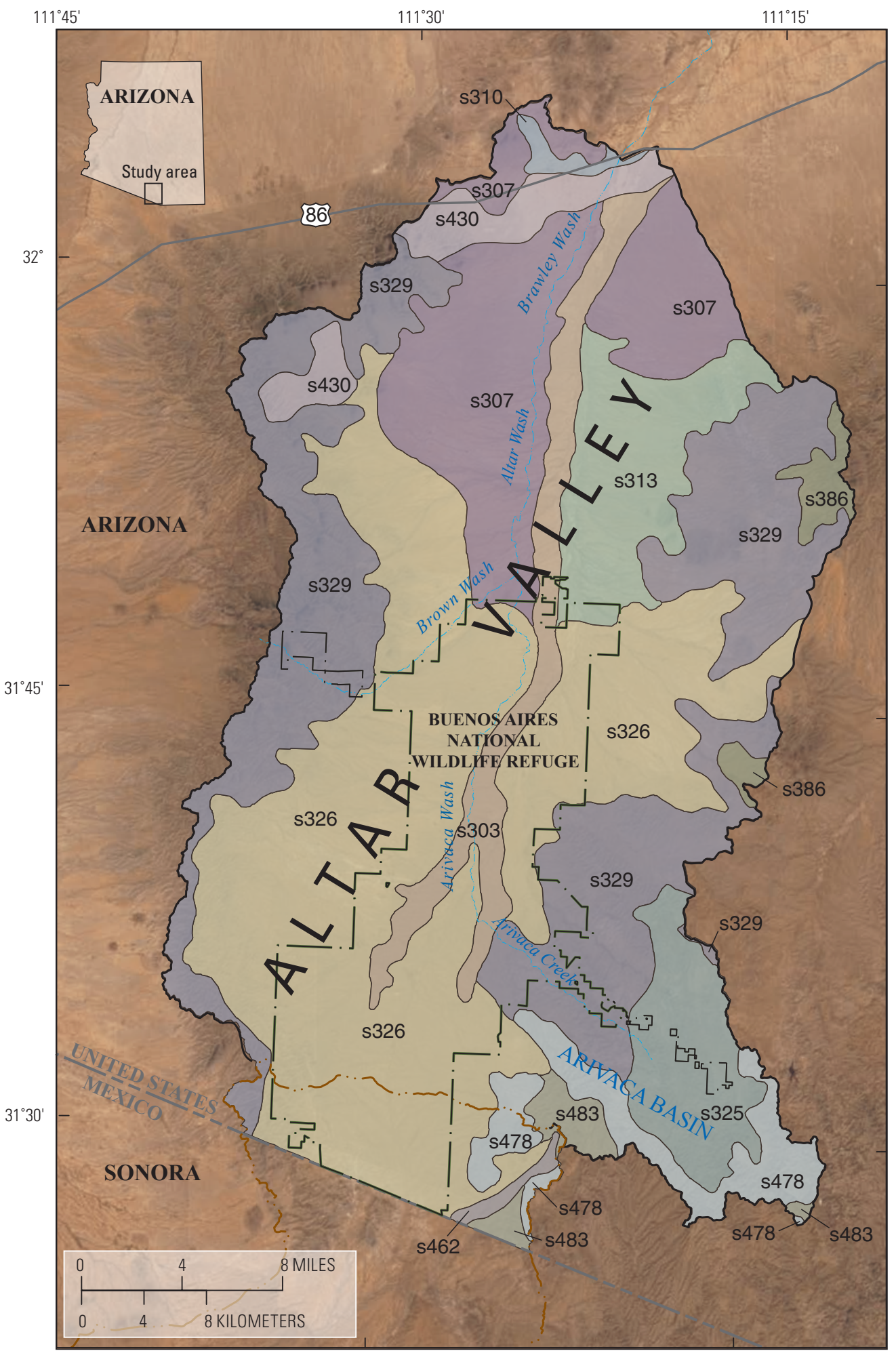

EXPLANATION

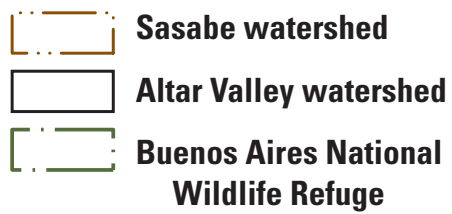

Wildlife Refuge

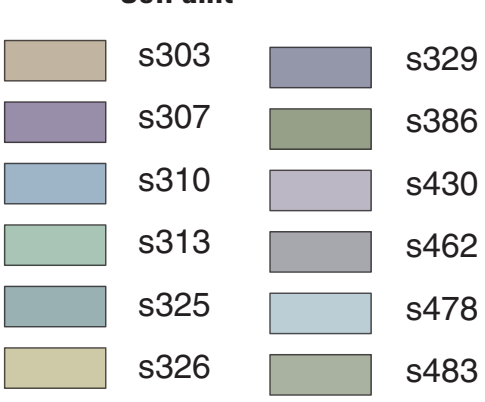

Figure 3. Satellite-image base map showing distribution of soil units within Altar Valley groundwater area (as delineated by U.S. Geological Survey [USGS]) and Buenos Aires National Wildlife Refuge (BANWR), Arizona. Soil units are from Natural Resources Conservation Service's State Soil Geographic Database (STATSGO) (Soil Survey Staff, U.S. Department of Agriculture, 2019a, c); see table 2 for brief descriptions of soil units. Boundary of Altar Valley groundwater area from Wilson (1991); BANWR boundary from U.S. Fish and Wildlife Service; watershed boundaries from USGS (2018). Satellite-image base map from Esri. Drainage features, national boundary, and road from USGS' The National Map (https://viewer. nationalmap.gov).

with the exception of a few wells along the perimeter of the basin. More recent studies such as the collection and modeling of gravity data have provided estimated depth to bedrock in sedimentary basins in Arizona (Oppenheimer and Sumner, 1980; Lysonski and others, 1980; Richard and others, 2007; see also, fig. 5, this report).

The water-bearing geologic units of BANWR, as mapped at the surface (Richard and others, 2000), consist of middle
Miocene to Pliocene deposits (unit Tsy) in the southern part of the refuge; latest Pliocene to early Pleistocene surficial deposits (unit QTo) in the central part of the refuge; and undivided Quaternary surficial deposits $(Q)$ in the northern part of the refuge. Haxel and others (1982) described the valley fill unit as "Quaternary/Tertiary gravel, undifferentiated: gravel, sand, and minor silt as unconsolidated to weakly consolidated, undissected to moderately dissected deposits in and along 
Table 2. Official Soils Series names and brief descriptions of soil units in Altar Valley groundwater area, Arizona.

[Soil units mapped in figure 3; mapped soil units and boundaries in figure 3, as well as Official Soil Series names and areal coverages below, are from Natural Resources Conservation Service's State Soil Geographic Database (STATSGO2) (Soil Survey Staff, U.S. Department of Agriculture [SSS USDA], 2019c). Percentages of rock fragments and soil texture classes are from Soil Survey Staff, U.S. Department of Agriculture (SSS USDA, 2019a). Areal coverages are percentages of each Official Soil Series within each mapped soil unit in Altar Valley groundwater area. Abbreviations: inches, in.; n/a, not applicable; wt. \%, weight percent]

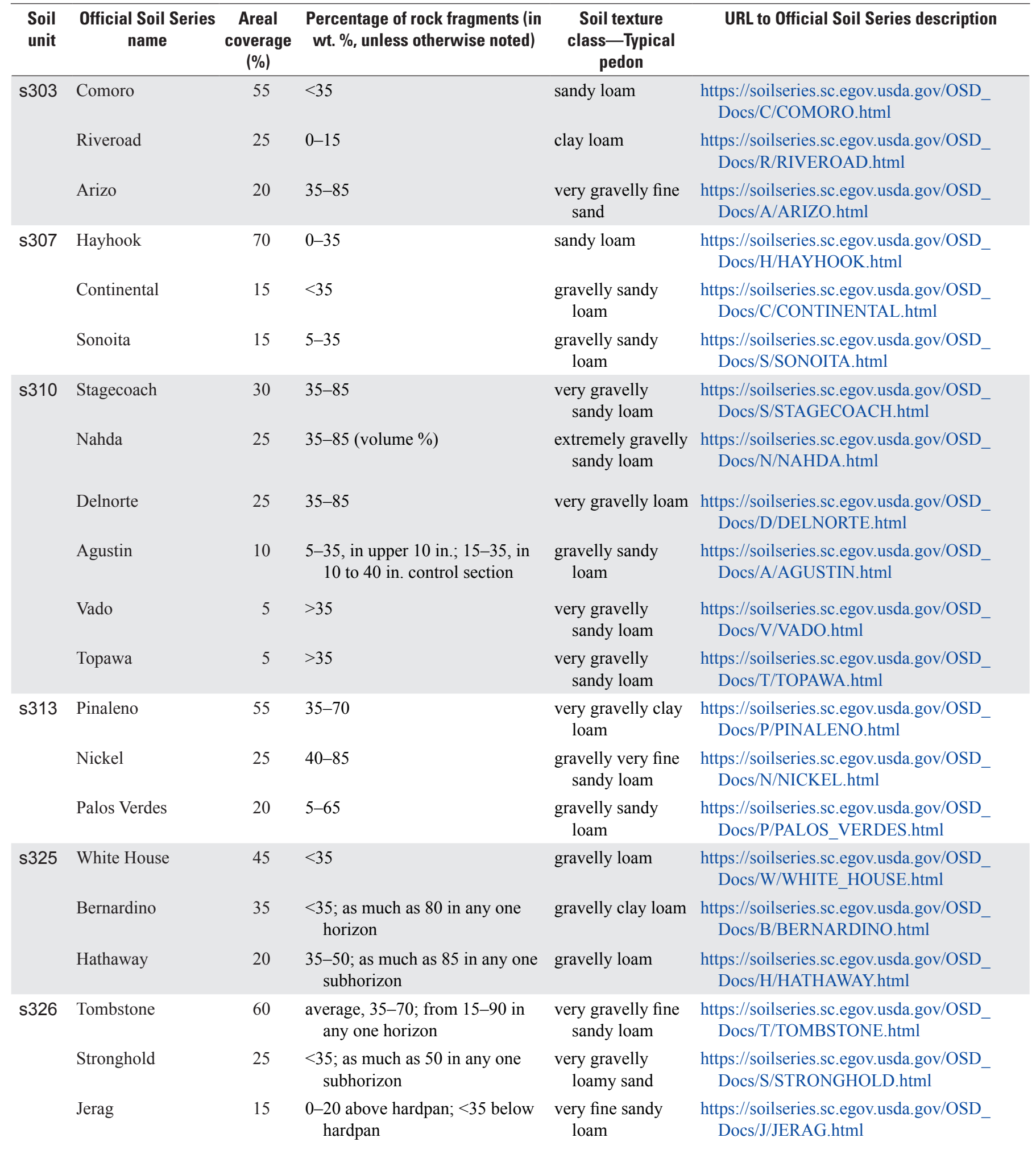


Table 2.- Continued

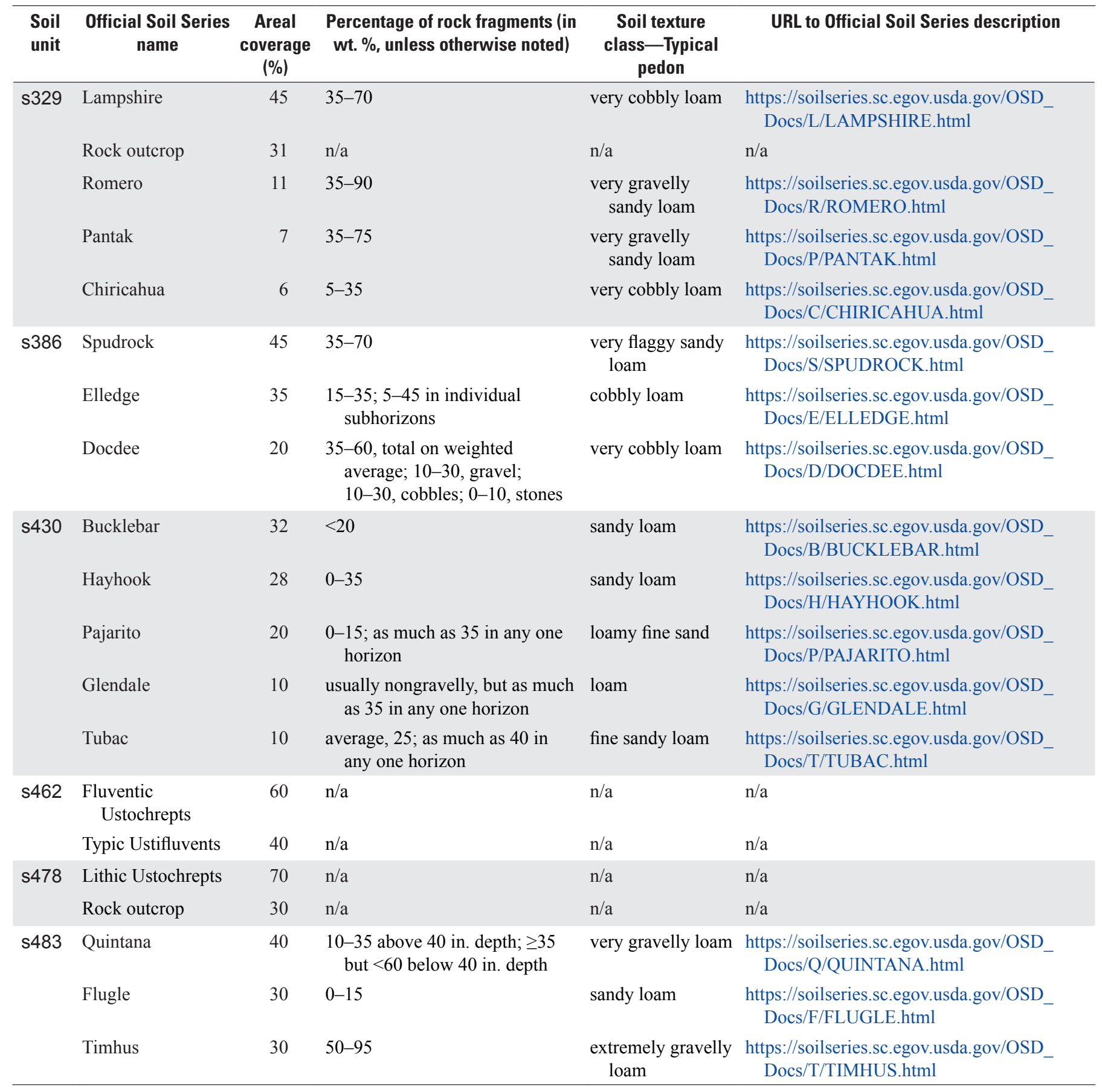

canyons, washes, and arroyos, near mouths of canyons, on pediments, in dissected alluvial fans and as fill of Altar Valley." Although not mapped herein, the Quaternary to Tertiary gravel was also reported by Haxel and others (1982) to be found as numerous small, thin, discontinuous patches that overlie bedrock along the east side of the Baboquivari and Pozo Verde Mountains, from Santa Margarita Ranch south to Sasabe. Underlying these deposits are the various types of waterbearing bedrock that make up the surrounding mountains.

A well at the BANWR visitor center (well D-21-08 27ADA1, fig. 1) was reported by Richard and others (2007) to be drilled into sedimentary and volcanic rocks that were mapped as Upper Jurassic to Cretaceous sedimentary rocks (unit KJs) that contained minor volcanic rocks, sandstone, and conglomerate, as well as a massive conglomerate typically near the base of unit KJs and also, locally, in the upper part of the unit (Richard and others, 2000). No log is available for well D-21-08 27ADA1, reported to be $400 \mathrm{ft}$ deep; however, well D-21-08 27ADA3, about $350 \mathrm{ft}$ to the south, was drilled to a depth of $500 \mathrm{ft}$ in what the driller described as "clay, gravel, and fragmented rock." Well D-21-08 16ADB2, about $2.25 \mathrm{mi}$ northwest of well D-21-08 27ADA1, was drilled to 


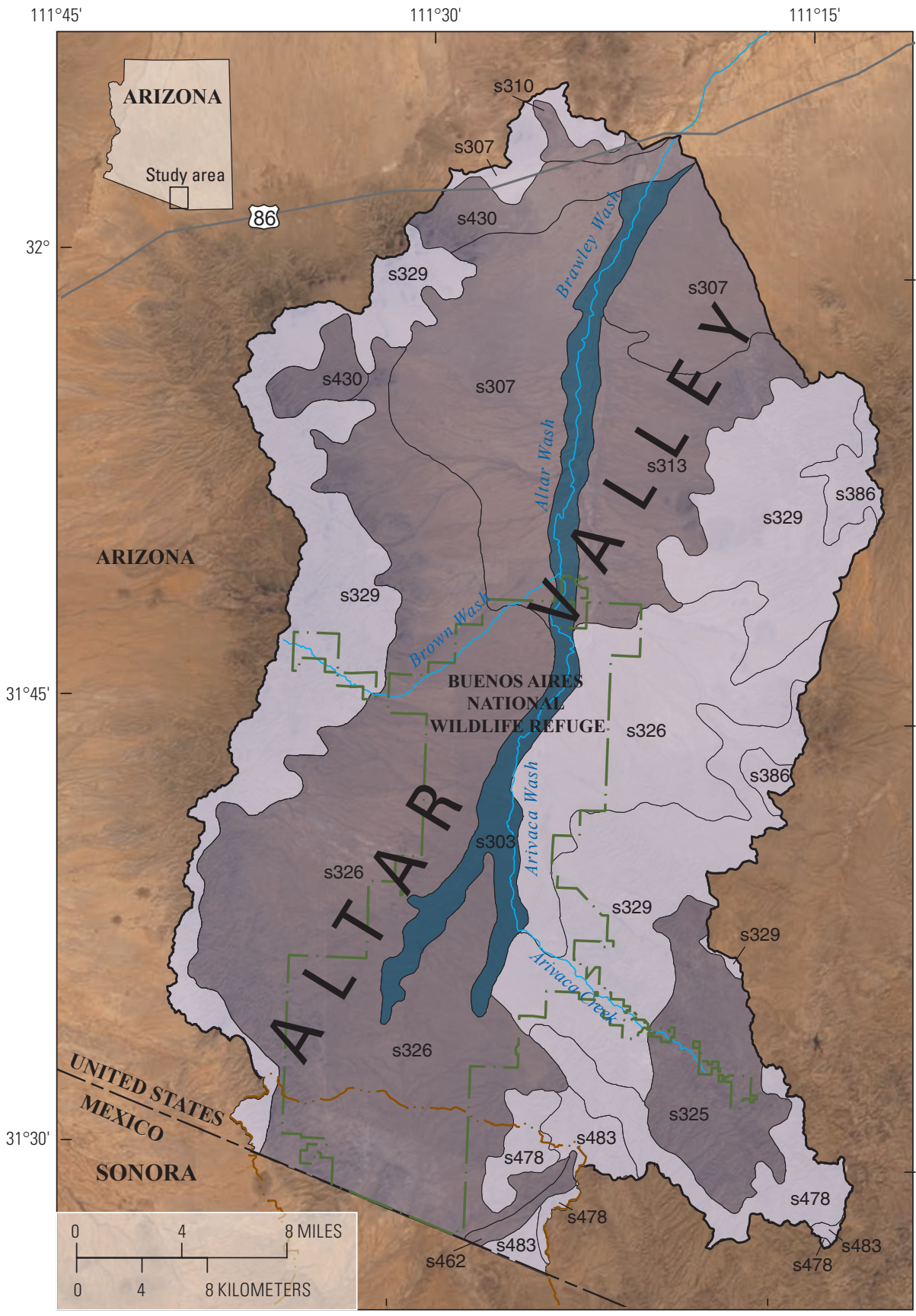

\section{EXPLANATION}

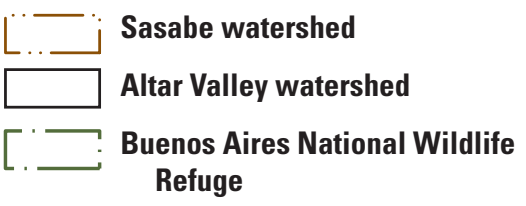

Saturated vertical hydraulic conductivity, in centimeters per second-Soil units and contacts from figure 3 shown for reference

$<0.0003$

$0.0003-0.030$

$>0.030$

Figure 4. Satellite-image base map showing saturated vertical hydraulic conductivity $(K v)$ of soil units in Altar Valley groundwater area (as delineated by U.S. Geological Survey [USGS]) and Buenos Aires National Wildlife Refuge (BANWR), Arizona, estimated from Natural Resources Conservation Service's State Soil Geographic Database (STATSGO) and individual soil-series data (Soil Survey Staff, U.S. Department of Agriculture, 2019a, c). Soil units and contacts from figure 3 shown for reference; see table 2 for brief descriptions of soil units. Boundary of Altar Valley groundwater area from Wilson (1991); BANWR boundary from U.S. Fish and Wildlife Service; watershed boundaries from USGS (2018). Satellite-image base map from Esri. Drainage features, national boundary, and road from USGS' The National Map (https://viewer.nationalmap.gov).

a depth of $600 \mathrm{ft}$, in what the driller described as "clay with gravel streaks and gravel increasing with depth" and which Richard and others (2007) mapped as middle Miocene to Pliocene deposits (unit Tsy) that consist of moderately to strongly consolidated conglomerate and sandstone, deposited in basins during and after late Tertiary faulting.

Many of the wells in Altar Valley were drilled before 1950 and, therefore, do not have associated drillers' logs to help determine depth to bedrock or underlying geologic formations. Some newer or replacement wells have drillers' logs, but these wells are scattered, and only six are located within BANWR. Wells that lie within the USGS groundwater area for Altar Valley (area ALT, in Wilson, 1991) are plotted on figure 5; data for those wells (current as of 2019) are stored in the
NWIS database, and selected data are listed in Owen-Joyce (2021; see also, brief discussion in appendix 1, this report).

A depth-to-bedrock map modeled from gravity data (Richard and others, 2007) indicated that depth to the bedrock that underlies late Tertiary to Quaternary basin fill (units Tsy, QTo, Q) near the BANWR wells is about $800 \mathrm{ft}$, and the basin deepens to the north and west on the refuge (see contours on fig. 5). Note that, for this depth-to-bedrock map (Richard and others, 2007), bedrock was defined in hydrogeologic terms - that is, rock that has sufficiently low bulk permeability such that it could not be an aquifer-and that basin fill refers to the sedimentary (and, locally, volcanic) materials that fill basins that were generally deposited since about 15 million years ago $(\mathrm{Ma})$ in the southern part of 
Arizona, in the Basin and Range province. Depth-to-bedrock contours were constructed to estimate the depth of the boundary between bedrock, which has a density greater than 2.67 grams per cubic centimeter $\left(\mathrm{g} / \mathrm{cm}^{3}\right)$, and basin fill, which has a density that varies between about 2.05 and $2.42 \mathrm{~g} / \mathrm{cm}^{3}$ (Oppenheimer and Sumner, 1980). Water-bearing, older rock units, such as the Upper Jurassic to Cretaceous sedimentary rocks unit (KJs), which yields water to the wells at the refuge headquarters, fall in the lower density range.

Analyzing bedrock is complex, especially not having data from wells drilled into bedrock units; in addition, various studies define bedrock differently. About 6 mi north of the refuge, a drill hole (fig. 1, well D-17-08 36DBD1) that was drilled in 1982 to test for oil to a depth of 9,021 ft bottomed in Cretaceous to Tertiary granitic rocks (probably unit TKgm) after penetrating Paleozoic, Cretaceous, Tertiary, and (or) Quaternary rocks. Tertiary granitic rocks were encountered at $7,741 \mathrm{ft}$, and a sample taken at 9,000 to $9,021 \mathrm{ft}$ was dated at 33.9 Ma using potassium-argon (K-Ar) methods and $50 \mathrm{Ma}$ using rubidium-strontium (Rb-Sr) methods (Phillips Petroleum, unpublished drillers' $\log$, accessed May 28, 2019, at http:// ogviewer.azdeq.gov/resources/og/OGPermitFiles/0797.pdf).

In the canyons along the edges of the basin, depth to bedrock is shallow (fig. 1). Wells D-19-08 17CBD2 and D-19-08 20ABB1 (fig. 5), drilled along Brown Canyon, have drillers' logs that indicate bedrock was penetrated at less than $25 \mathrm{ft}$. Where Arivaca Creek cuts between the San Luis and Las Guijas Mountains to flow into Altar Valley (fig. 1), depth to bedrock is shallow. Near Arivaca Creek, well D-21-09 $13 \mathrm{ABC} 1$ (fig. 5) penetrated bedrock at $15 \mathrm{ft}$, but drillers' logs for wells off the floodplain show bedrock at the surface. In the Arivaca Basin east of the Las Guijas and San Luis Mountains, late Tertiary to Quaternary basin fill (units Tsy, QTo) overlies bedrock. A depth-to-bedrock map simulated from gravity (Richard and others, 2007) indicated that depth to bedrock exceeds $400 \mathrm{ft}$ in the center of Arivaca Basin (fig. 5).

\section{Surface Water}

Altar Valley is drained by many washes that flow in response to rainfall and drain into Altar and Brawley Washes. The USGS currently monitors streamflow at two gaging stations $^{3}$ located in the main axis of the Altar Valley watershed (figs. 1, 2): at Altar Wash near Three Points (station number 09486800; hereafter Altar Wash gage); and farther downstream at Brawley Wash near Three Points (station number 09487000; hereafter Brawley Wash gage). The Altar Wash gage represents runoff from the southern part of Altar Valley, whereas the Brawley Wash gage represents runoff from the entire Altar Valley. Altar Wash becomes Brawley Wash about 8 mi upstream from the watershed outlet, and both are ephemeral (fig. 1). Stock tanks, filled by runoff in washes and by wells, are scattered throughout Altar Valley and the surrounding hills. Although it is unlikely that the stock tanks affect the regional aquifer, stock tanks are potential, locally important sources of groundwater recharge.

Complete annual-streamflow records for both the Altar Wash and Brawley Wash gages exist from 1993 to 2018 (U.S. Geological Survey [USGS], 2019a), including years within the current (2000 to 2019) drought period. Complete annualstreamflow records for the Altar Wash gage also are available from 1966 to 1974 (USGS, 2019a), which are years without drought; runoff, which normally is highest during the months of July, August, and September, during the summer monsoonal season, was higher in the period from 1966 to 1974 than in the nondrought years (table 3); peak streamflow has varied from 696 cubic feet per second $\left(\mathrm{ft}^{3} / \mathrm{s}\right)$ in 2002 to $22,000 \mathrm{ft}^{3} / \mathrm{s}$ in 1970 . The Brawley Wash gage has been in operation since 1992, with some peak streamflow measurements available starting in 1940; since 1994, peak streamflow has varied from $58 \mathrm{ft}^{3} / \mathrm{s}$ in 1994 to $11,800 \mathrm{ft}^{3} / \mathrm{s}$ in 2005 . Streamflow measured at these two gages indicates generally lower values during the period from 2001 to 2017 (USGS, 2019a; see also, fig. 6, this report).

Arivaca Creek is one of the main tributaries to Altar Wash that historically has had seasonally present base flow. Although not active at present, several gaging stations have been in operation: Arivaca Wash near Arivaca (station number 09486600) (fig. 7A); Arivaca Creek at Arivaca (station number 09486580) (fig. 7B); and Arivaca Creek near Arivaca (station number 09486590) (fig. 7C). Gage 09486600, which has records from 1967 to 1972 , was located about $3.6 \mathrm{mi}$ northwest of the eventual location of the other two gaging stations; peak streamflow varied from a low of $260 \mathrm{ft}^{3} / \mathrm{s}$ in September 1970 to a high of 15,900 ft $3 / \mathrm{s}$ in December 1965 (indirect record) (USGS, 2019a). Gage 09486580, which

\footnotetext{
${ }^{3}$ Annual streamflow data at gaging stations are available from USGS National Water Information System database at https://waterdata.usgs.gov/ nwis/ (U.S. Geological Survey, 2019a), referenced by station number.
}

Table 3. Mean monthly streamflow at gaging stations in Altar Valley, Arizona.

[Data from U.S. Geological Survey (2019b). See figure 1 for locations. Abbreviation: $\mathrm{ft}^{3} / \mathrm{s}$, cubic feet per second]

\begin{tabular}{|c|c|c|c|c|c|c|c|c|c|c|c|c|}
\hline \multirow[b]{2}{*}{ Years } & \multicolumn{12}{|c|}{ Mean monthly streamflow (ft $3 / s)$} \\
\hline & Jan & Feb & Mar & Apr & May & Jun & Jul & Aug & Sep & Oct & Nov & Dec \\
\hline \multicolumn{13}{|c|}{ Brawley Wash near Three Points (station number 09487000) } \\
\hline \multicolumn{13}{|c|}{ Altar Wash near Three Points (station number 09486800) } \\
\hline $1993-2018$ & 0.16 & 0.15 & 0.02 & 0.01 & 0.00 & 2.50 & 15.2 & 15.7 & 9.41 & 1.25 & 0.23 & 0.27 \\
\hline
\end{tabular}




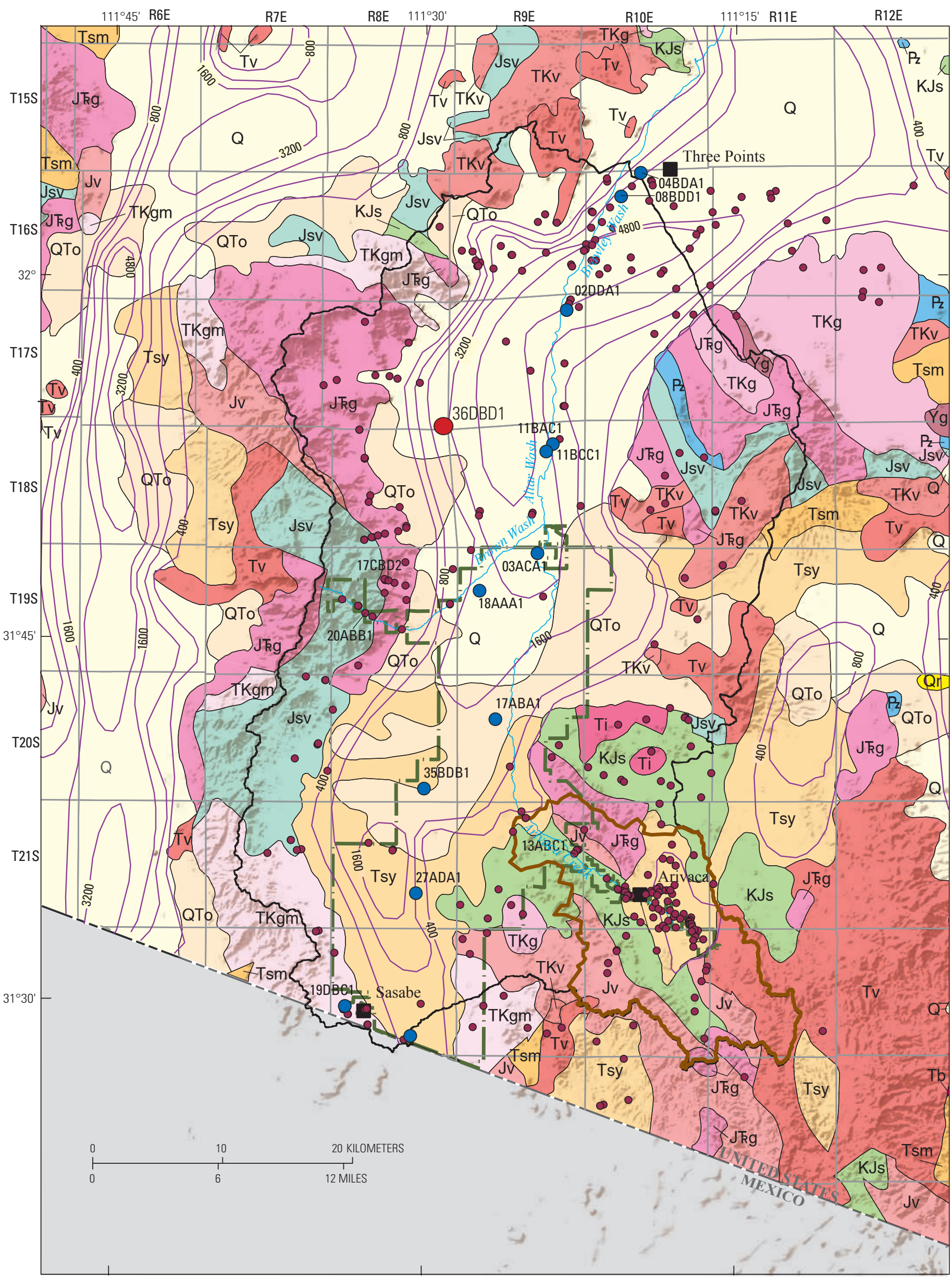




\section{EXPLANATION}

Quaternary surficial deposits, undivided-Unconsolidated to very well consolidated alluvial and eolian deposits. Includes coarse, poorly sorted alluvial fan and terrace deposits on middle and upper piedmonts and along large drainages; sand, silt and clay on alluvial plains and playas; and wind-blown sand deposits. Age of unit is 0 to $2 \mathrm{Ma}$

Qr Holocene river alluvium-Unconsolidated to weakly consolidated sand and gravel, in river channels; includes sand, silt, and clay, on floodplains. Also includes young terrace deposits that fringe floodplains. Age of unit is 0 to $10 \mathrm{ka}$

QTo Early Pleistocene to latest Pliocene surficial deposits-Coarse relict alluvial fan deposits that form rounded ridges or flat, isolated surfaces that are moderately to deeply incised by streams. Moderately to strongly consolidated; commonly contains sediment that is coarser grained than younger deposits in the same area. Deposits generally are topographically high and have undergone substantial erosion. Age of unit is 0.75 to $3 \mathrm{Ma}$

Tsy Pliocene to middle Miocene sedimentary rocks-Moderately to very well consolidated conglomerate and sandstone, generally light gray or tan Includes lesser amounts of mudstone, siltstone, limestone, and gypsum. Deposited in basins during and after late Tertiary faulting; commonly forms high rounded hills and ridges in modern basins, locally forming prominent bluffs. Widely exposed in dissected basins of southeastern and central Arizona. Age of unit is 2 to $16 \mathrm{Ma}$

Late to middle Miocene basaltic rocks-Mostly dark basalt deposited as mesa-forming lava flows. Rocks were not tilted by middle Tertiary normal faulting. Age of unit is 8 to $16 \mathrm{Ma}$

Tsm Middle Miocene to Oligocene sedimentary rocks-Conglomerate, sandstone, mudstone, limestone, and rock-avalanche breccia (sheetlike deposits of crushed rock). Conglomerate and sandstone commonly are medium to dark brown, reddish brown, or brownish gray; younger strata generally are lighter colored. Deposited and tilted during widespread normal faulting and basin development. Age of unit is 11 to $32 \mathrm{Ma}$, mostly 20 to $30 \mathrm{Ma}$ (in southeastern Arizona) and 15 to $25 \mathrm{Ma}$ (in central and western Arizona)

Tv Middle Miocene to Oligocene volcanic rocks-Lava flows, tuff, fine-grained intrusive rocks, and diverse pyroclastic rocks. Compositionally variable: includes basalt, andesite, dacite, and rhyolite. Age of unit is 11 to $38 \mathrm{Ma}$, mostly 20 to $30 \mathrm{Ma}$ (in southeastern Arizona) and 15 to $25 \mathrm{Ma}$ (in central and western Arizona)

Ti Middle Miocene to Oligocene shallow-intrusive rocks-Generally very fine grained, porphyritic rhyolite to dacite. Includes small, irregular-shaped bodies formed as subvolcanic intrusions, in volcanic fields of southern and western Arizona. Age of unit is 14 to $35 \mathrm{Ma}$

TKgm Early Tertiary to Late Cretaceous muscovite-bearing granitic rocks-Light-colored peraluminous muscovite granite that either has or does not have garnet; associated with abundant pegmatite dikes and sills, and commonly forms sills. Unit includes several muscovite-bearing granites in southern Arizona that are associated with calc-alkaline granites of unit TKg. Unit typically represents youngest phase of voluminous magmatism during Laramide orogeny in Arizona. Age of unit is 50 to $80 \mathrm{Ma}$

TKg Early Tertiary to Late Cretaceous granitic rocks-Porphyritic to equigranular granite to diorite; emplaced during the Laramide orogeny. Larger plutons characteristically are medium-grained, hornblende- and (or) biotite-bearing granodiorite to granite; smaller, shallow-level intrusions are typically porphyritic. Most large copper deposits in Arizona are associated with porphyritic granitic rocks of this unit and, thus, are named "porphyry copper deposits." Age of unit is 50 to $82 \mathrm{Ma}$

TKv Late Tertiary to Late Cretaceous volcanic rocks-Rhyolite to andesite; includes closely associated near-surface intrusive rocks; also includes minor sedimentary rocks. Commonly dark gray to dark greenish gray or greenish brown. In ranges west of Tucson, includes thick welded ash-flow tuffs. Unit is restricted to southeastern Arizona. Inferred to have been derived from vents and volcanoes above magma chambers that solidified to form granitic rocks of unit TKg. Age of unit is 50 to $82 \mathrm{Ma}$

KJs Cretaceous to Upper Jurassic sedimentary rocks-Sandstone and conglomerate; also includes minor volcanic rocks. Sandstones are typically medium-bedded, drab brown, lithic-feldspathic arenites; massive conglomerates are typical near base of unit and, locally, in upper part. Rarely forms prominent outcrops. Rocks are nonmarine, except in southeastern Arizona. Age of unit is 80 to $160 \mathrm{Ma}$

Jsv Jurassic sedimentary and volcanic rocks, undifferentiated-Sandstone, siltstone, and conglomerate, mostly derived from volcanic rocks; also contains limestone and associated intermediate-composition lava flows, breccias, and tuffs. Characterized by maroon, brown, and purplish-gray volcanic-lithic sandstone and siltstone, with subordinate to abundant conglomerate, quartz-rich sandstone, and sparse limestone. Age of unit is 150 to $170 \mathrm{Ma}$

$\mathrm{Jkg}$ Jurassic and Triassic granitic rocks-Granite to diorite, locally foliated and locally alkalic. Includes dark, foliated or gneissic diorite; medium-grained, equigranular to porphyritic granodiorite; and small, irregular intrusions of light-colored, fine-grained granite. Age of unit is 150 to $180 \mathrm{Ma}$

JV Jurassic volcanic rocks-Massive quartz-feldspar porphyry, generally interpreted as thick, welded rhyolitic tuffs; also includes locally abundant lava flows and sandstone and conglomerate derived from volcanic rocks; in southern Arizona, interbedded with rare, eolian quartzite. Age of unit is 160 to $200 \mathrm{Ma}$

$\mathrm{P}_{\mathrm{Z}} \quad$ Paleozoic sedimentary rocks-Undivided Paleozoic limestone, dolostone, quartzite, shale, and related sedimentary rocks. Age of unit is 248 to $544 \mathrm{Ma}$

Yg Middle Proterozoic granitic rocks-Mostly porphyritic biotite granite that has large microcline phenocrysts and, locally, fine-grained border phases and aplite; associated pegmatite and quartz veins are rare. Forms large plutons. Age of unit is 1,400 to 1,450 Ma

Arizona Department of Water Resources index well

- Altar Valley well

Oil test drill hole D-17-08 36DBD1

Contact

- 400 - Depth-to-bedrock contours - Contours in feet

Altar Valley groundwater area

Buenos Aires National Wildlife Refuge (BANWR)

Arivaca Basin
Figure 5. Shaded-relief geologic map of Altar Valley groundwater area (as delineated by U.S. Geological Survey [USGS]) and Buenos Aires National Wildlife Refuge (BANWR), Arizona; geology modified from Richard and others (2000). Also shown are depth-to-bedrock contours (in feet; from Richard and others, 2007), various well locations, and an oil test drill hole. Locations of wells and oil test drill hole from National Water Information System (USGS, 2020). Boundary of Altar Valley groundwater area from Wilson (1991); BANWR boundary from U.S. Fish and Wildlife Service. Drainage features, national boundary, and road from USGS' The National Map (https://viewer.nationalmap.gov). 
was installed in 1995, was discontinued in 2002; at the time of discontinuance, gage 09486590 was established about $200 \mathrm{ft}$ upstream from gage 09486600 . Gage 09486590 was operational through October 2014. Combined data from these two gages indicate peak streamflow varied from a low of $0.00 \mathrm{ft}^{3} / \mathrm{s}$ in 2012 to a high of 2,200 $\mathrm{ft}^{3} / \mathrm{s}$ in July 2007

(USGS, 2019a). Streamflow records in Arivaca Creek show that, despite considerable interannual variability, there were often seasonal cycles in base flow: after a period of no flow in spring, base flow typically begins in July with the onset of the summer monsoonal season and continues through the following spring (USGS, 2019a); however, summer base flow stopped after 2010, possibly the result of long-term drought reducing groundwater levels (fig. 7).

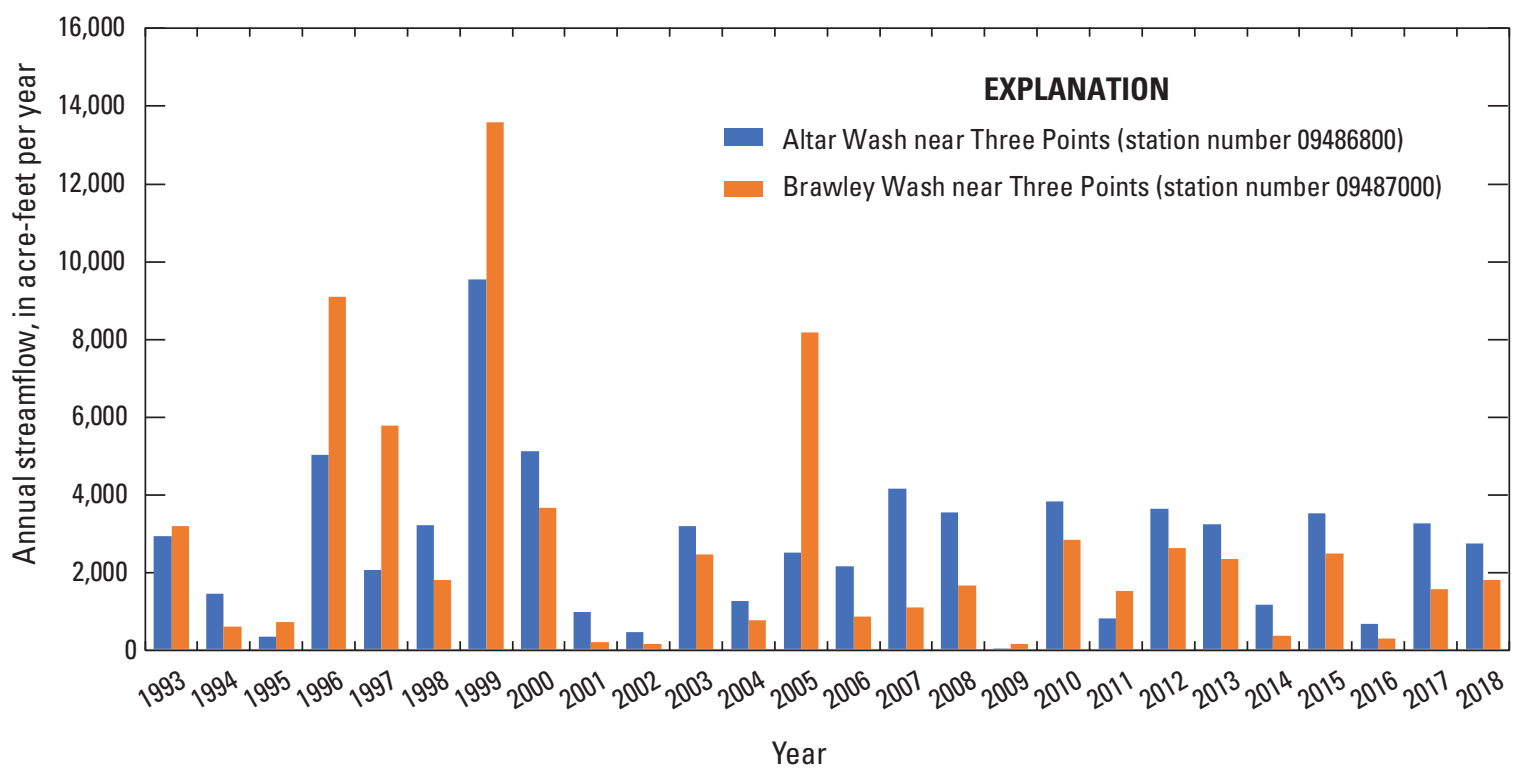

Figure 6. Graph showing annual streamflow at Altar Wash near Three Points (station number 09486800) and at Brawley Wash near Three Points (station number 09487000), Arizona, from 1993 to 2018 (data from U.S. Geological Survey, 2019a).

A. Arivaca Wash near Arivaca (station number 09486600)

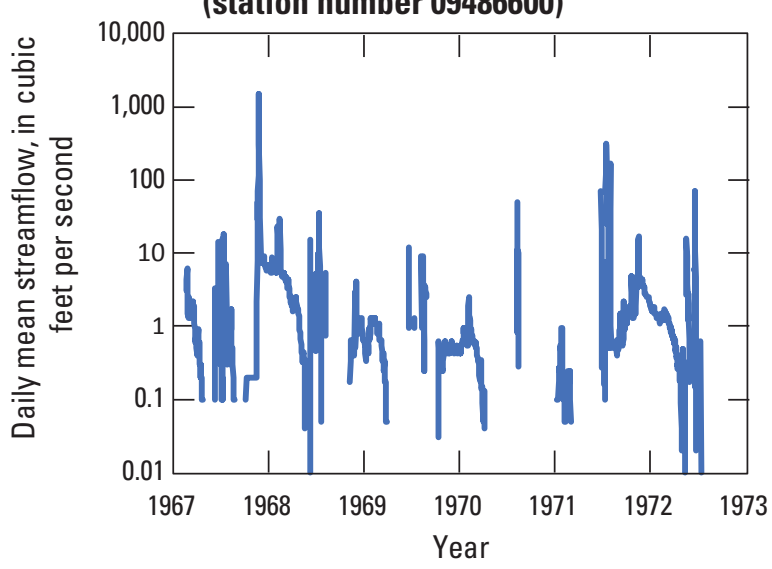

C. Arivaca Creek near Arivaca (station number 09486590)

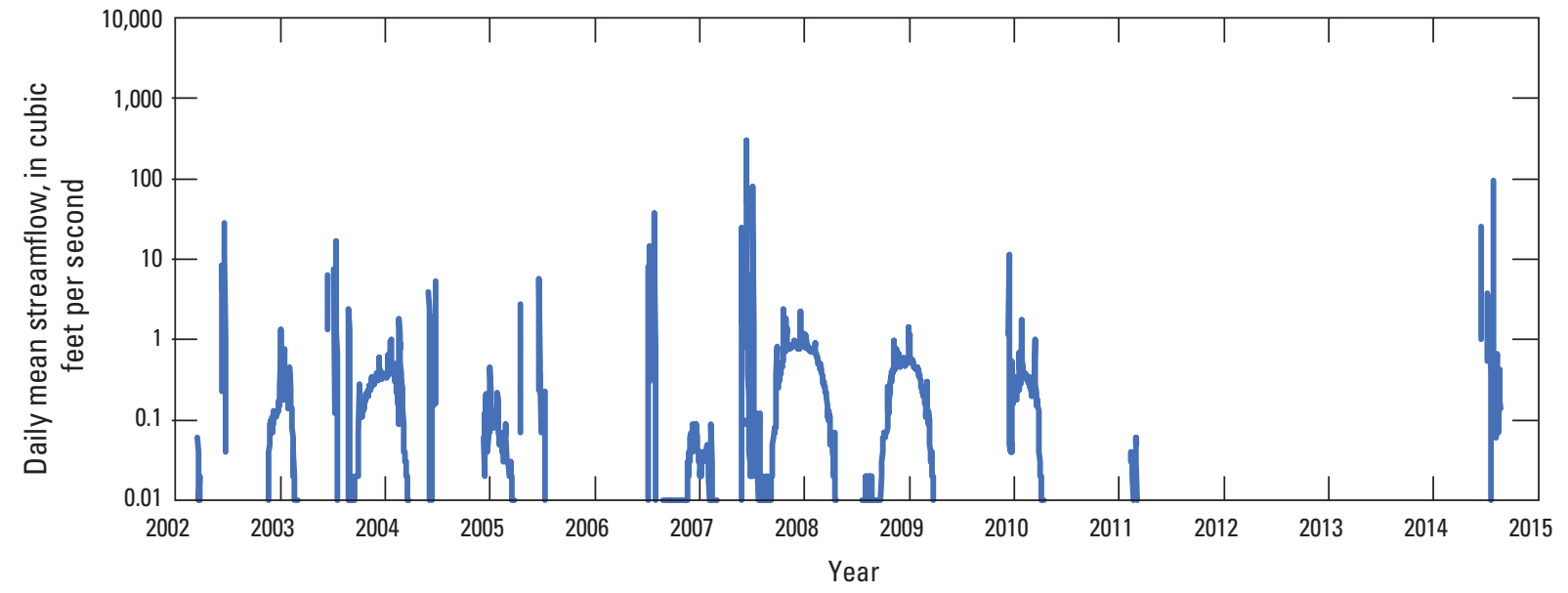

B. Arivaca Creek at Arivaca (station number 09486580)

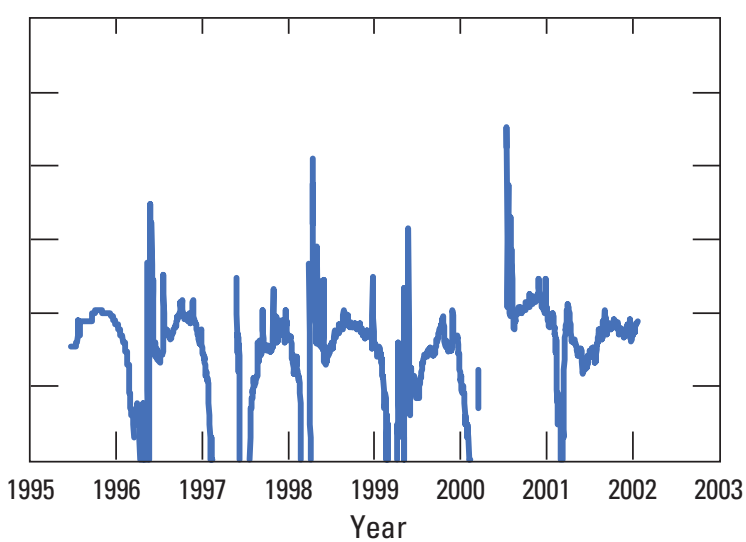

\section{(3)}

a

\section{Creek near Arivaca}

(station number 09486590), Arizona, for variable periods of record (data from U.S. Geological Survey, 2019a). Note that, because zero cannot be shown on log scale, data less than 0.1 are either missing or indicate zero flow. 


\section{Groundwater}

Groundwater data are important in understanding groundwater recharge, movement, and discharge through an aquifer system. Water-level data in wells provides information on flow direction and, with long-term time series, can demonstrate the extent of water-level stability in an aquifer. Beginning in the 1950s, USGS selected wells to take repeated water-level measurements, generally annually, as part of an index-well network for Arizona. In the 1980s, ADWR took over the index-well network and expanded it with additional wells. The index wells in Altar Valley are located down the center of the basin from north to south.

Groundwater levels, combined with drillers' logs, provide information on what geologic formation the water is coming from. Groundwater data for this study were compiled from multiple sources:

- USGS National Water Information System (NWIS) (https://waterdata.usgs.gov/nwis/);

- Unpublished USGS original paper records at the USGS Arizona Water Science Center, Tucson, Ariz.;

- ADWR groundwater site inventory (https://gisweb. azwater.gov/waterresourcedata/gwsi.aspx);

- ADWR well registry (https://gisweb.azwater.gov/ waterresourcedata/WellRegistry.aspx); and

- ADWR imaged records (https://infoshare.azwater. gov/docushare/dsweb/HomePage).

Satellite imagery was used to visually locate new wells registered with ADWR and also to update the location data on existing wells from the NWIS and ADWR databases. The locations of all 35 wells were updated on the refuge, but only selected wells were updated outside the refuge (in Altar Valley) because of funding constraints. The compiled data were entered or updated in NWIS. ${ }^{4}$ Many of the well logs were downloaded from the ADWR well registry (drilled after 1980) or the imaged records (drilled before 1980). Some logs for older wells were in the USGS paper files. ${ }^{5}$ Groundwaterlevel data were collected over time by USGS, ADWR, and the University of Arizona. All the available groundwater-level data were merged and added to the NWIS database for use in our analyses to maximize the period of record.

Springs are found in the mountainous areas of the Altar Valley groundwater area, and four of them have been inventoried (none in BANWR). An attempt was made to locate springs using visual inspection of satellite images; however, most springs were not identifiable, even when noted on the topographic maps. Possible reasons are that (1) some springs may flow only in response to rainfall, (2) vegetation can hide flow, and (or) (3) the springs may have ceased flowing because

\footnotetext{
${ }^{4}$ Well-site information and groundwater-level data can be accessed from the USGS National Water Information System database at https://nwis.waterdata. usgs.gov/nwis/ (U.S. Geological Survey, 2019a); groundwater-level data can be viewed and downloaded in tabular and graphic form.

${ }^{5}$ Well logs matched to individual wells in NWIS are available in the paper records of USGS, Arizona Water Science Center, Tucson, Arizona.
}

of drought; fieldwork would be required to ground truth the actual location of the springs.

Inflow to the aquifer likely enters as infiltration of mountain-front runoff in the various streams that drain the mountains and hills surrounding Altar Valley (Eastoe and Wright, 2019). The mountains that bound the west side of the northern part of the valley are higher and, therefore, receive more precipitation than those in the south, and they likely have higher rates of recharge. Bedrock is shallow, less than $800 \mathrm{ft}$ and, in places, at the land surface at the south end of the valley near the U.S.-Mexico border (fig. 5). The shallow bedrock may indicate that a groundwater divide is located south of the drainage divide near the border, but well data are lacking to delineate its location. A water-level-contour map for the part of the valley that extends into Mexico showed that groundwater flows southward from near the border (CONAGUA [Comisión Nacional del Agua], 2018, their fig. 6). Water-level-contour maps of the valley north of the border (Hammett and Sicard, 1995, their sheet 1), as well as a plot of water levels from 10 of the 12 index wells along the central axis of Altar Valley (figs. 1, 8), showed that, in BANWR, groundwater flows northward in Altar Valley into the northern part of the valley and eventually into Avra Valley. The existence of a groundwater divide contributes to the lack of a water source in the south to replenish the declining wells, as does the lower elevations in the southern parts of the basin-bounding mountain ranges that result in lower annual precipitation. Depth to water ranges from 200 to $300 \mathrm{ft}$ at the south end of the valley near the border, as well as along the Altar and Brawley Washes in the central part of the valley, to greater than $400 \mathrm{ft}$ along the margins of the valley (Hammett and Sicard, 1995, their sheet 2). Where tributary streams enter the valley along the edges of the basin fill, the alluvial material is shallow and was deposited on bedrock. Depending on what rock unit makes up the bedrock in a given area and (or) if it is fractured, water in wells is either perched on the bedrock or can be obtained from drilling into bedrock, and the depth to water is less than $100 \mathrm{ft}$. A number of wells are situated in Brown Canyon (figs. 1, 5), but only two newer wells have logs: well D-19-08 20ABB1 is drilled into limestone, below $5 \mathrm{ft}$ of alluvial material; and well D-19-08 17CBD2 is drilled into what the driller described as "quartz granite bands and limestone," below $21 \mathrm{ft}$ of alluvial material.

Groundwater in Arivaca Basin is forced to the surface where a shallow contact between alluvium and less permeable bedrock is present near Arivaca cienega. Arivaca Creek is perennial where the creek begins in Arivaca cienega and also for a short distance downstream where it flows westward over bedrock before entering the subsurface again (Schorr, 2005). Depth to groundwater in the Arivaca Basin varies from 0 to $200 \mathrm{ft}$ (Hammett and Sicard, 1995, their sheet 2). Groundwater exits the Arivaca Basin either as base flow in Arivaca Creek or as subflow in the alluvium along the creek, and it discharges into Altar Valley.

Groundwater levels in wells monitored by the ADWR throughout Altar Valley rose between 0 and $25 \mathrm{ft}$ between 1980 to 1981 and 1994 to 1995 (Hammett and Sicard, 1995, 
their sheet 3). Water levels between 1993 and 2013 declined in the southern part of Altar Valley, from 5 to $11 \mathrm{ft}$, and increased in the northern part of the valley, from $<1$ to $4 \mathrm{ft}$ (Davis and others, 2014). Water levels between 2006 and 2016 continued to decline in the southern part of Altar Valley and Arivaca Basin from 1 to $9 \mathrm{ft}$, but in the northern part, they rose from $<1$ to $2 \mathrm{ft}$ (ADWR, 2017, their plate 14).

The declining groundwater levels are of concern to resource managers at BANWR, given the request in 2018 for additional pumping from well D-21-08 27ADA1 at the refuge headquarters, the level of which has been declining since 1990. Although wells in the southern part of the valley are used for domestic- and stock-water purposes, none are high production. Wells mainly located along the borders of the valley intercept groundwater recharge.
ADWR has compiled annual pumpage data since 1984 for each well that pumps more than 35 gallons per minute ( $\mathrm{gal} / \mathrm{min}$ ) in the Avra Valley Subbasin of the TAMA (accessed March 27, 2020, at http:/www.azwater.gov/querycenter/ query.aspx?qrysessionid=9D766144C04C8E37E0534C648 50A58D9). Those data were obtained and then subdivided to separate the Altar Valley part of the Avra Valley Subbasin. The Altar Valley data were further subdivided into the northern area, where water levels have not been declining, and the southern area, where water levels have been declining (appendix 2); Arivaca Basin is included in the southern part of the valley. Annual pumpage amounts have increased in the northern part of the valley during the drought that began in 2000, but they have not increased in the southern part (fig. 9), where groundwater levels are declining. One cause could be

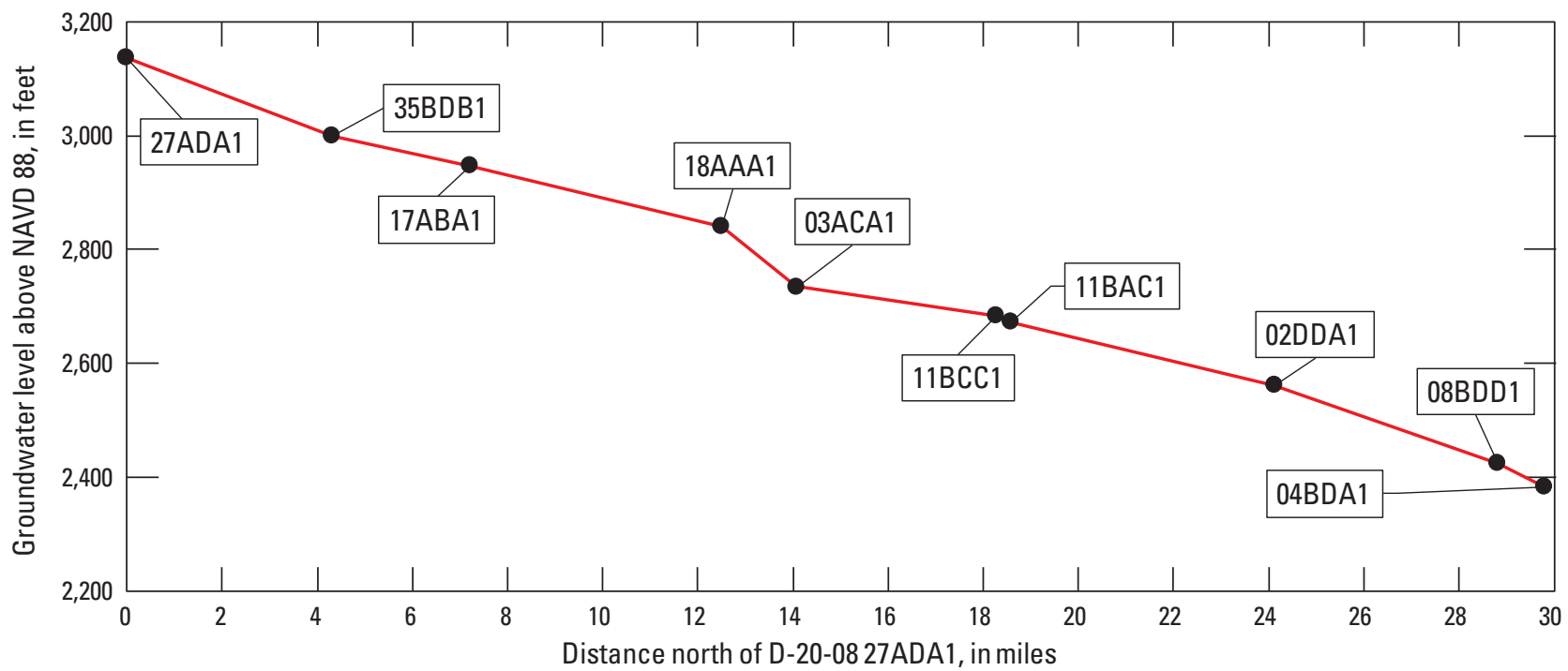

Figure 8. Plot showing water levels from January 2019, plotted using data from index wells (black dots) shown in figure 1 (well names shown in rectangles; see figure 1 for locations); data from U.S. Geological Survey (2019b). Data show groundwater gradient from south to north along center of Altar Valley, Arizona: well 27ADA1 is located at Buenos Aires National Wildlife Refuge headquarters; well 04BDA1 is located near Highway 86. Note that data from wells farther south were not plotted because they are located in separate watershed that drains southward into Sonora, Mexico; location of groundwater divide is unknown.

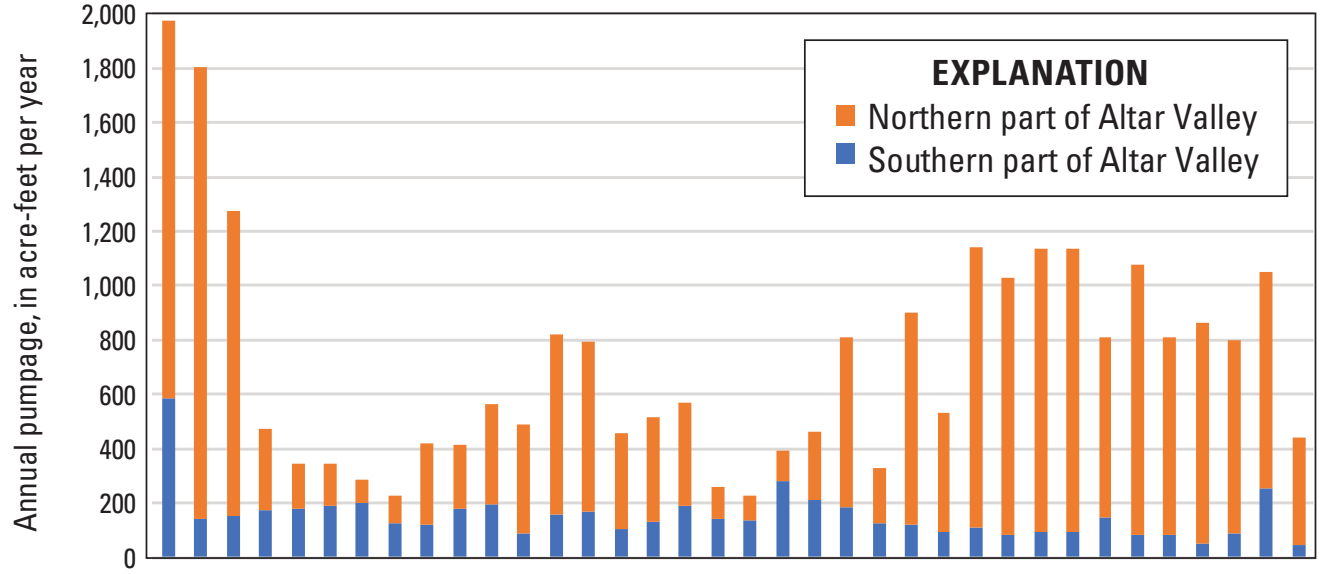

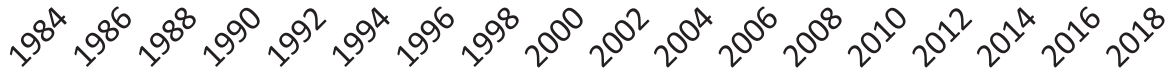

Figure 9. Graph showing comparison of annual pumpage from wells that pump more than 35 gallons per minute between northern and southern parts of Altar Valley, Arizona, between 1984 and 2019; data from Arizona Department of Water Resources (2018; see also, appendix 2, this report). 
lower elevations in the southern parts of the basin-bounding mountain ranges, resulting in lower annual precipitation and associated recharge amounts. In Mexico, groundwater flows southward, and so no source of water from the south is available to replenish supply to the wells with declining water levels. Additional collection of geophysical data could help delineate the basin in the southern and central parts of the valley, where the water level declines, and also help increase understanding of the hydrologic system.

As to the comparatively stable groundwater levels in the north even though pumpage has increased there since the 1990s, pumpage is still about half what is was in the early 1980s. Water levels in most wells in the north were drawn down prior to the decrease in pumping in the early 1980 s, possibly owing to a combination of pumping and the nearly $15-\mathrm{yr}$ midcentury drought that occurred between 1942 and 1956 (Thomas, 1962). Water levels were in the process of recovering when the increase in pumping occurred in the 1990s (fig. 9). Because the water levels were recovering instead of static, the increased pumping may have only limited the recovery rather than caused a decrease in water levels, as a new quasiequilibrium was reached. Additional possible causes for the stability in groundwater levels include (1) an upgradient aquifer transmissivity high enough to offset pumping, (2) a low-permeability barrier, such as bedrock or clay, at the north end of the valley that allows for groundwater poolings, (3) a higher lateral inflow of groundwater in the northern part of the valley, (4) a delay in the effect of storage declines propagating from the south, or (5) some combination thereof.

\section{Altar Valley Precipitation- Groundwater Level Correlation}

The correlation between precipitation and groundwater levels in Altar Valley was analyzed using the USGS HydroClimATe Toolkit (Dickinson and others, 2014). Input data included PRISM (Parameter-elevation Relationships on Independent Slopes Model) data (PRISM Climate Group, 2019) and groundwater-level data from the NWIS (USGS, 2019b). PRISM data represent a modeled interpolation of climate that uses datasets from numerous sources (Daly and others, 2008, their table 3). These interpolated datasets reflect continuous spatial climate patterns in the United States (Daly and others, 2008). Precipitation and temperature data were selected from the PRISM dataset for an area within BANWR, in the center of the valley (approx lat $31.7795^{\circ} \mathrm{N}$., long $111.4350^{\circ}$ W.) (PRISM Climate Group, 2019). The 3-yr moving averages of annual precipitation and temperature were compared to the 123-yr median values to assess annual departures from the median. The median was used instead of the mean to avoid skewing caused by extreme values. The 3-yr moving average was used as a filter to emphasize multiyear and decadal climatic trends, rather than annual variability (fig. 10).

Groundwater-level data, collected from 12 active index wells that are generally located along the central axis of Altar Valley (fig. 1), were obtained from the NWIS database (USGS, 2019b). With few exceptions, water-level data were only available on an annual basis. Most measurements were made

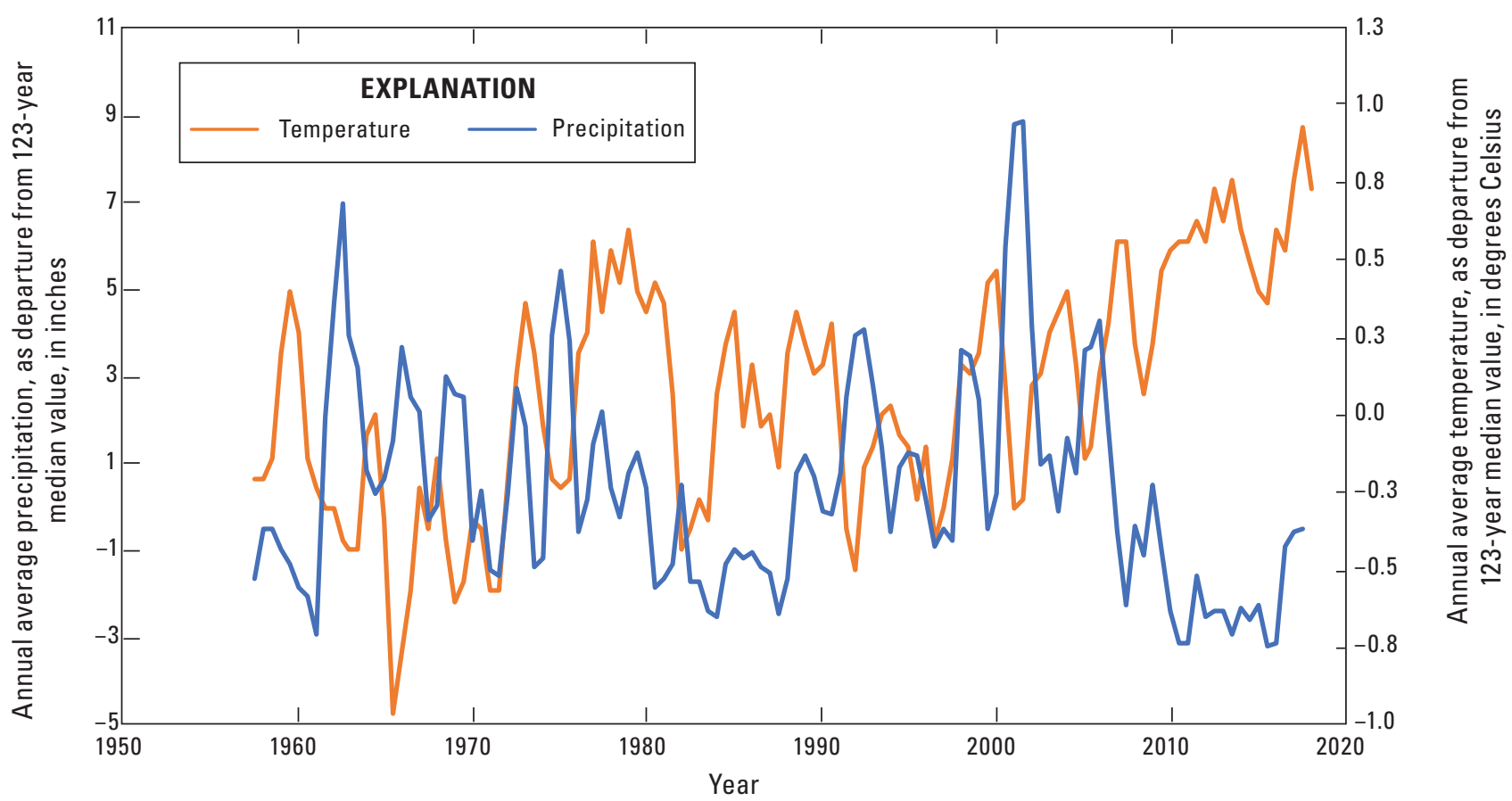

Figure 10. Plot showing annual average precipitation and temperature in Altar Valley, Arizona, plotted as 3-year movingaverage departure from 123-year median-precipitation and -temperature values; data, which are centered at lat $31.7795^{\circ}$ N. and long $111.4350^{\circ}$ W., are from PRISM Climate Group (2019). 
during the months of November through February. Values described as taken during or soon after a period of pumping were removed from the dataset used in the correlation analysis in order to represent static conditions. Wells that have multiple water-level measurements recorded for a year were averaged to correspond to PRISM annual precipitation data (PRISM Climate Group, 2019). Review of water-level trends between 1995 and 2019 indicated the presence of two distinct groups, one in the north and one in the south (figs. 11, 12). With the exception of well D-19-09 18AAA1, groundwater-level trends in the southern group of wells all exhibited statistically significant declines (table 4), whereas those in the north had weak trends or no trend.

To assess the link between variability in precipitation and variability in groundwater levels, one well in each group (well D-17-09 02DDA1 [in the north] and D-22-08 19DBC1 [in
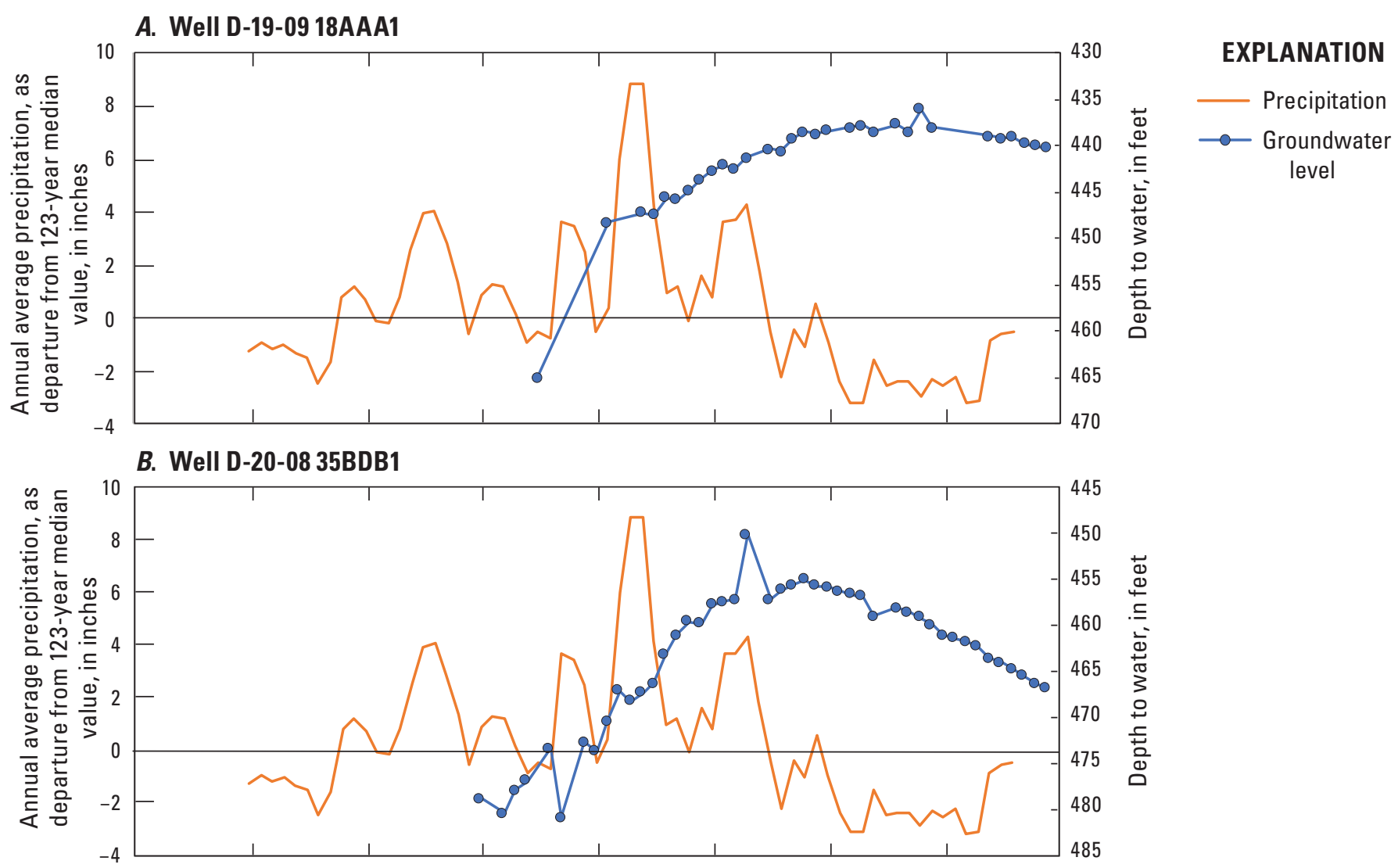

C. Well D-21-09 17ABA1

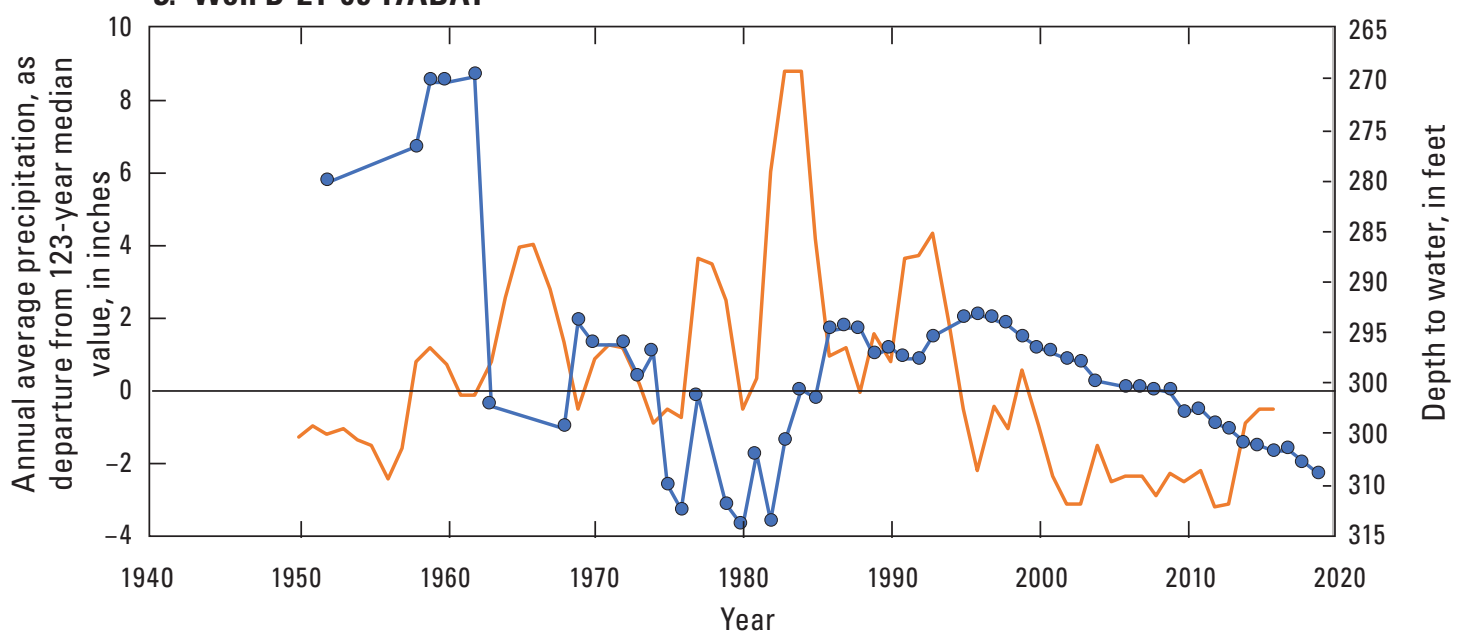

Figure 11 (pages 18-19). Plots showing depth to water for selected wells and average annual precipitation in southern part of Altar Valley, Arizona. Precipitation plotted as 3-year moving-average departure from 123-year median-precipitation values; precipitation data, which are centered at lat $31.7795^{\circ} \mathrm{N}$. and long $111.4350^{\circ} \mathrm{W}$., are from PRISM Climate Group (2019). A, Well D-19-09 18AAA1. B, Well D-20-08 35BDB1. C, Well D-20-09 17ABA1. D, Well D-21-08 27ADA1. E, Well D-22-08 19DBC1. F, Well D-22-08 34ABA1. 
the south]; fig. 1) was evaluated using lag-correlation analysis (Dickinson and others, 2014) to assess the possibility of a lag (time shift) between changes in precipitation and changes in groundwater levels. Lag-correlation analysis can be used to investigate the temporal relation between a causal physical process and a response. We used the 3-yr moving average of precipitation because recharge processes tend to average and smooth the precipitation input signal. Wells were chosen for location, for length and completeness of record, and for the similarity of their trend to that of others in either the northern or the southern part of the valley. Preliminary steps included interpolation and standardization (using a normal distribution) of the precipitation and well water-level time series. This was followed by linear regression calculated at each of 756 monthly lags of the standardized water-level time series $( \pm 30 \mathrm{yr})$. The correlation coefficient $(r)$ was calculated at each lag,
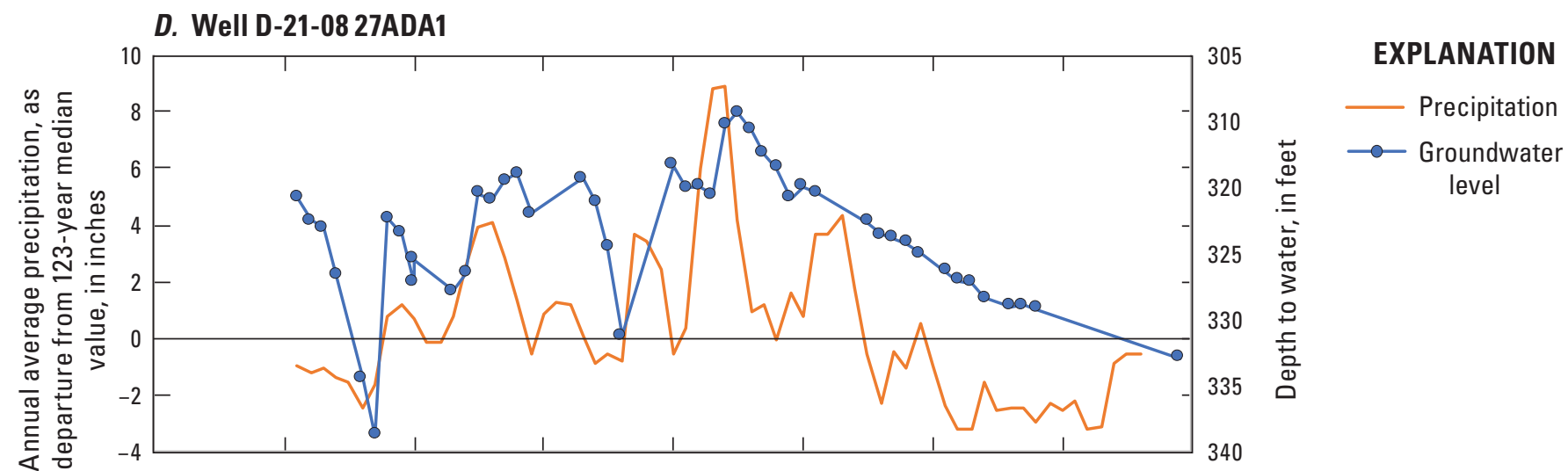

E. Well D-22-08 19DBC1

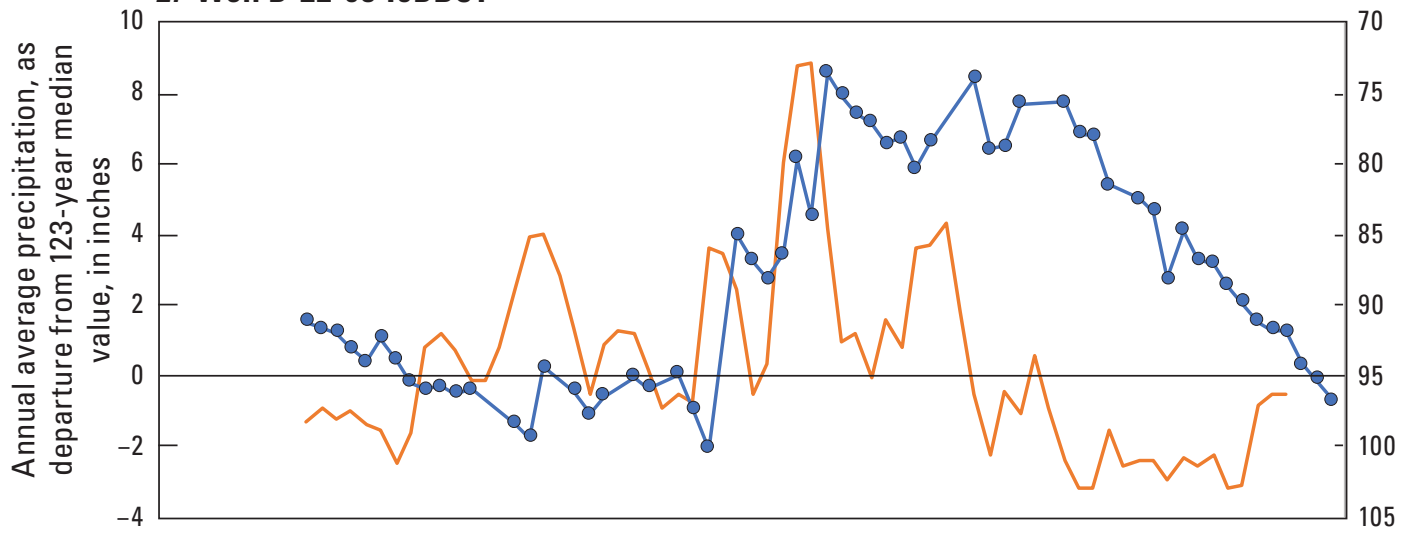

F. Well D-22-08 34ABA1

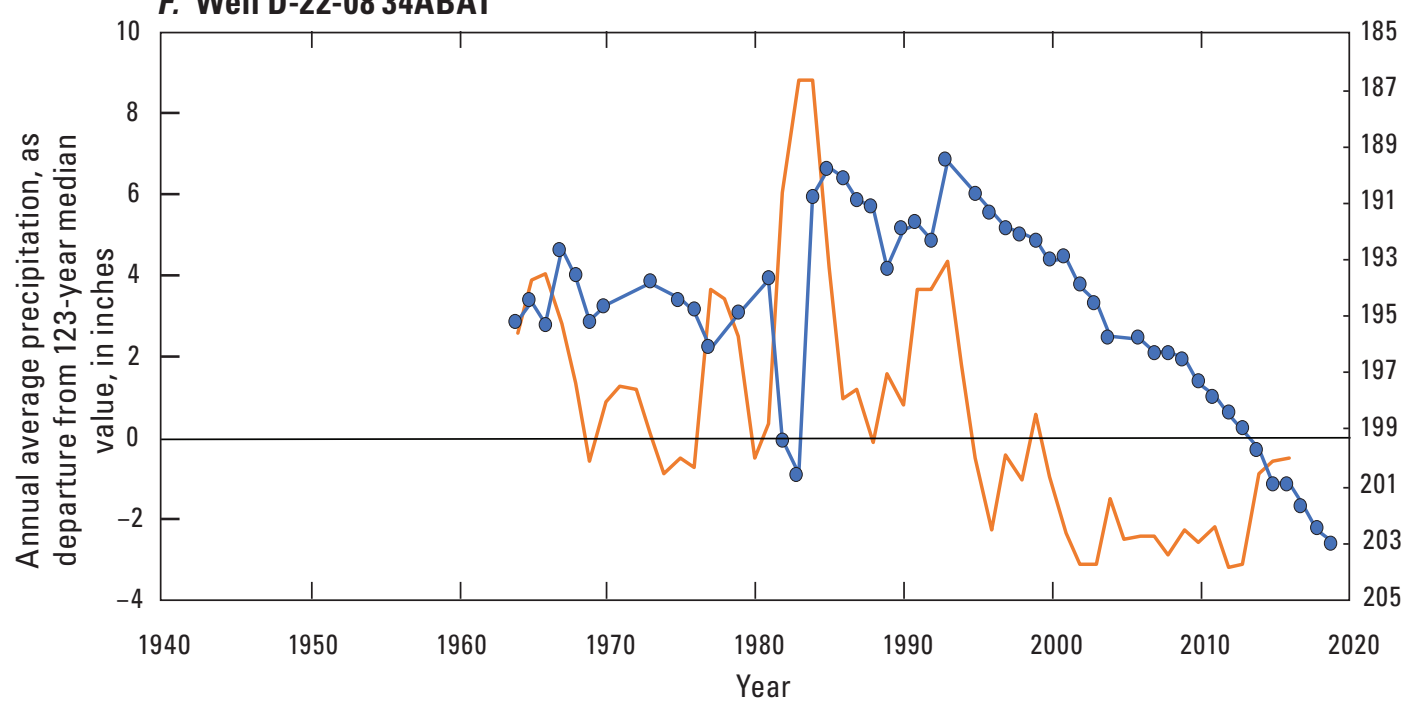

Figure 11 (pages 18-19).—Continued 

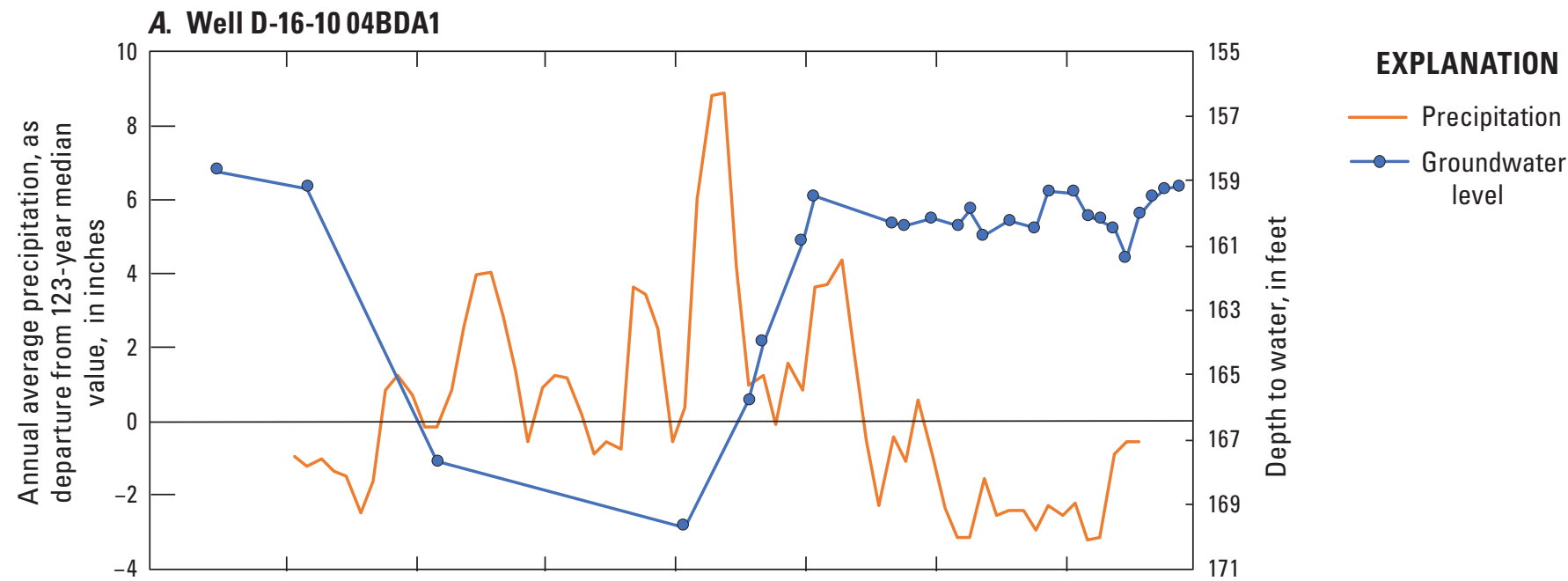

B. Well D-16-10 08BDD1
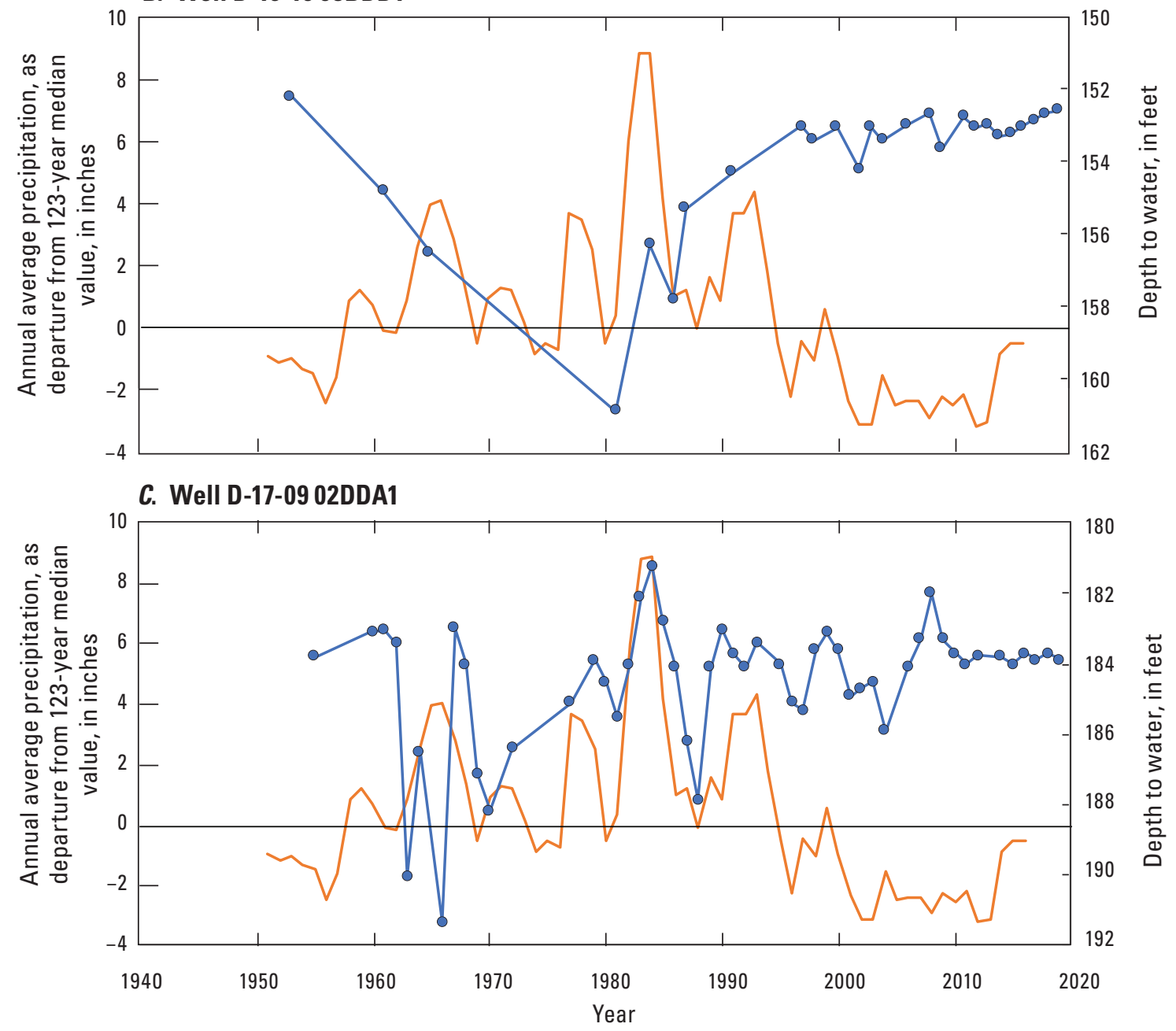

Figure 12 (pages 20-21). Plots showing depth to water for selected wells and average annual precipitation in northern part of Altar Valley, Arizona. Precipitation plotted as 3-year moving-average departure from 123-year median-precipitation values; precipitation data, which are centered at lat $31.7795^{\circ} \mathrm{N}$. and long $111.4350^{\circ} \mathrm{W}$., are from PRISM Climate Group (2019). $A$, Well D-16-10 04BDA1. B, Well D-16-10 08BDD1. C, Well D-17-09 02DDA1. D, Well D-18-09 11BAC1. E, Well D-18-09 11BCC1. F, Well D-19$0903 A C A 1$. 

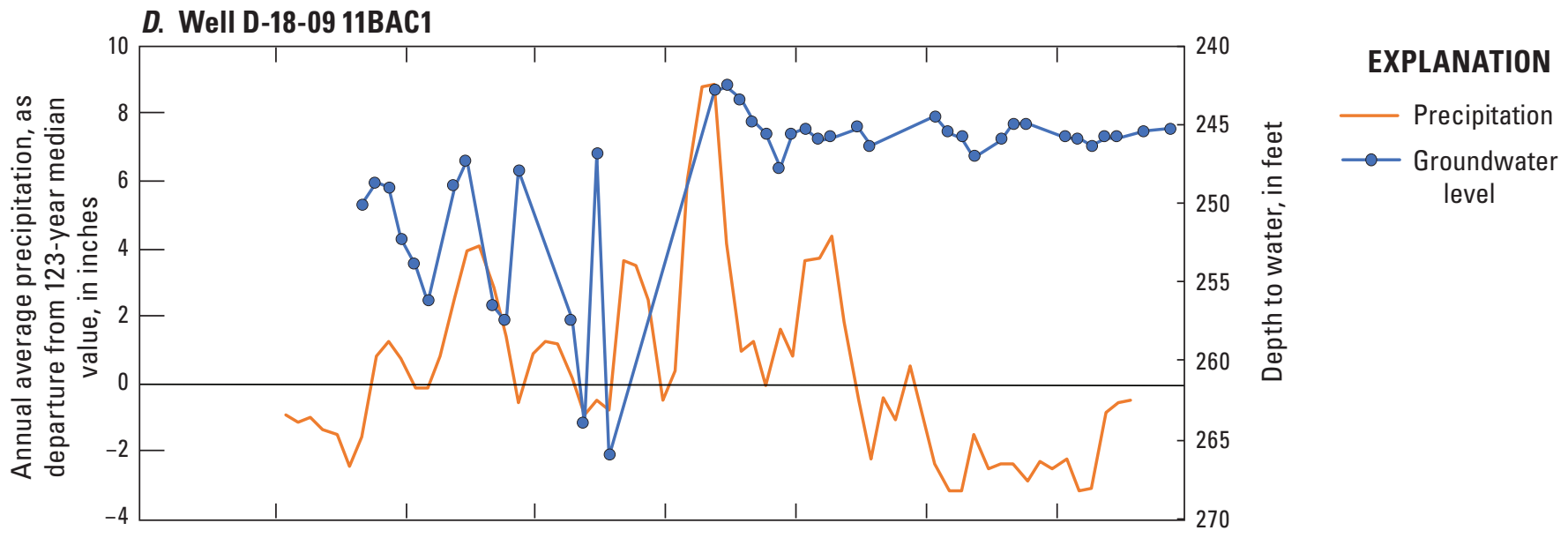

E. Well D-18-09 11BCC1
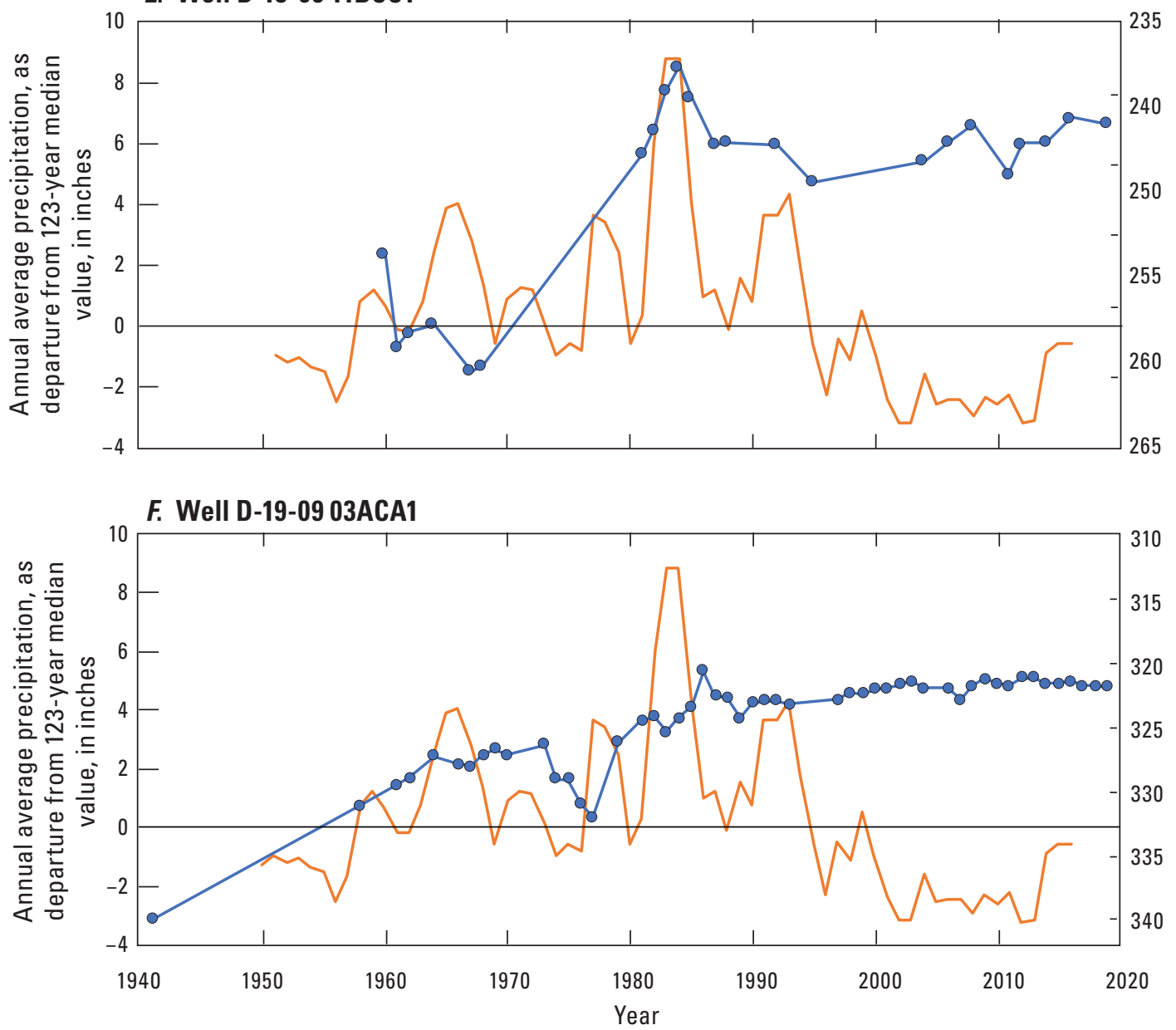

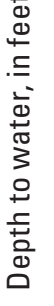

Figure 12 (pages 20-21).-Continued

ranked according to magnitude, and assessed for significance at the 95-percent confidence level. Given the presumption that, at this location, increases in water levels correspond to increases in precipitation, the lag that has the highest positive correlation coefficient was selected and interpreted as the time required for precipitation-induced recharge to propagate through the aquifer system to the well. The results of the lagcorrelation analysis indicate a generally shorter propagation time between recharge and groundwater at well D-22-08 19DBC1, in the southern part of Altar Valley (fig. 13), than at well D-17-09 02DDA1, in the northern part of the valley (fig. 14). Although a significant positive cor-relation with precipitation exists that varies from 2 to $21 \mathrm{yr}$ at the southern well (D-22-08 19DBC1), the maximum is at about $17 \mathrm{yr}$ $(r=0.34)$, which indicates that recharge affecting this well can occur over a range of time periods and also, potentially, from 
Table 4. Water-level-trend assessment of Altar Valley, Arizona, using the nonparametric Mann-Kendall statistic.

[Data from U.S. Geological Survey (2020). Mann-Kendall statistic from Salmi and others (2002); see footnotes for detailed descriptions of parameters. --, not applicable]

\begin{tabular}{|c|c|c|c|c|c|c|c|}
\hline Station name & Site identification no. & First year & Last year & $n^{1}$ & Test $\mathbf{S}^{2}$ & Test $Z^{3}$ & Significance level $(\alpha)^{[4]}$ \\
\hline D-19-09 18AAA1 & 314657111271501 & 1995 & 2019 & 19 & -- & -0.4 & No trend \\
\hline D-20-08 35BDB1 & 313850111295701 & 1995 & 2019 & 24 & -- & -6.1 & 0.001 \\
\hline D-20-09 17ABA1 & 314135111263101 & 1995 & 2019 & 24 & -- & -6.6 & 0.001 \\
\hline D-21-08 27ADA1 & 313429111301501 & 1995 & 2019 & 13 & -- & -4.6 & 0.001 \\
\hline D-22-08 19DBC1 & 312946111334501 & 1995 & 2019 & 22 & -- & -5.8 & 0.001 \\
\hline D-22-08 34ABA1 & 312827111303301 & 1995 & 2019 & 24 & -- & -6.7 & 0.001 \\
\hline D-16-10 04BDA1 & 320414111193001 & 1997 & 2019 & 18 & -- & 1.7 & 0.1 \\
\hline D-16-10 08BDD1 & 320313111203201 & 1997 & 2019 & 18 & -- & 2.2 & 0.05 \\
\hline D-17-09 02DDA1 & 315825111230601 & 1995 & 2019 & 23 & -- & 1.0 & No trend \\
\hline D-18-09 11BAC1 & 315257111234501 & 1995 & 2019 & 16 & -- & 0.0 & No trend \\
\hline D-18-09 11BCC1 & 315241111240301 & 1995 & 2019 & 9 & -21 & -- & 0.05 \\
\hline D-19-09 03ACA1 & 314830111243101 & 1997 & 2019 & 22 & -- & 2.5 & 0.05 \\
\hline
\end{tabular}

${ }^{1} \mathrm{n}$, number of annual values in calculation, excluding missing values.

${ }^{2}$ Test $\mathrm{S}$, used for $\mathrm{n}<10$; absolute value of $\mathrm{S}$ is compared to probabilities of Mann-Kendall trend test (see table A18, in Gilbert, 1987) to define if monotonic trend is at selected significance level. Positive values indicate upward trend; negative values indicate downward trend.

${ }^{3}$ Test $Z$, used for $\mathrm{n} \geq 10$; absolute value of $\mathrm{Z}$ is compared to standard normal cumulative distribution to identify if trend is at selected significance level. Positive values indicate upward trend; negative values indicate downward trend.

${ }^{4}$ Significance level $(\alpha)$, smallest significance level at which null hypothesis of no trend should be rejected.

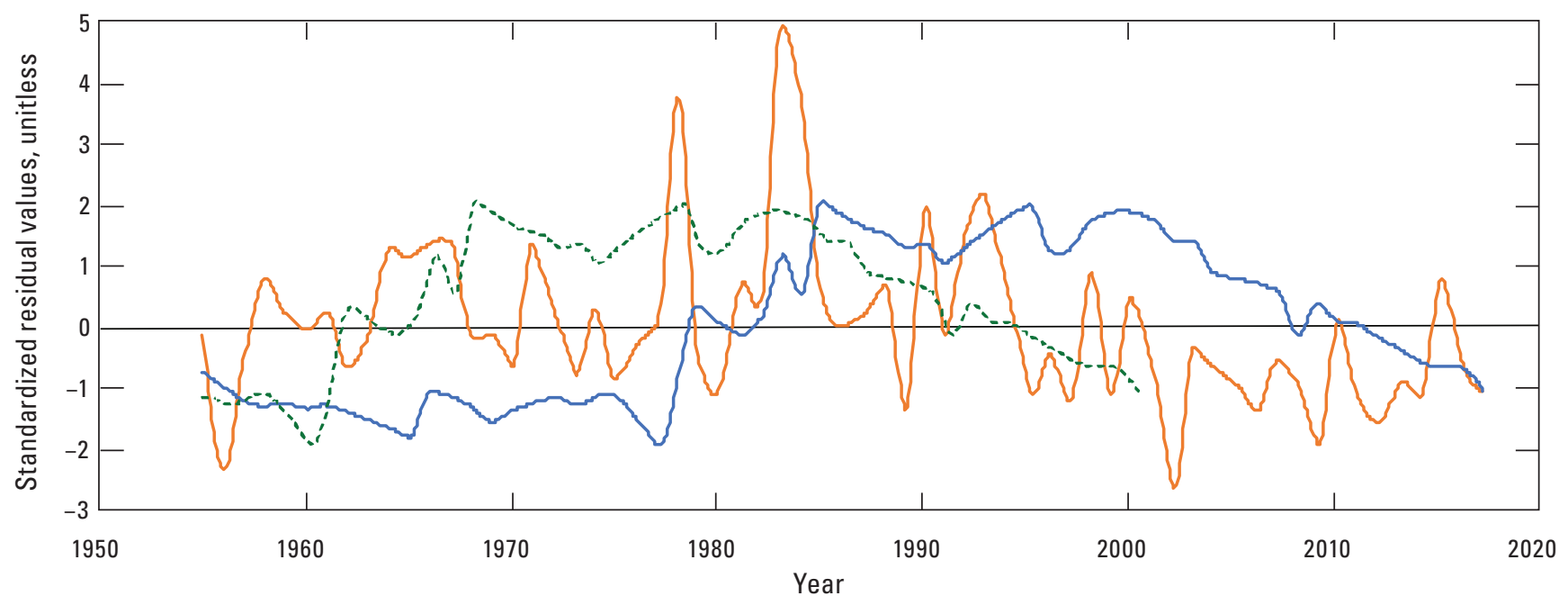

EXPLANATION

— Precipitation $\quad$ Groundwater level at well 19DBC1 -.--... Groundwater level (lagged 17 years)

Figure 13. Plot of lag correlation analysis (Dickinson and others, 2014), showing unitless standardized residual values of (1) precipitation, (2) groundwater levels at well D-22-08 19DBC1 in southern part of Altar Valley, Arizona, and (3) groundwater levels lagged 17 years.

a range of locations but that maximum coupling occurs at a lag of about $17 \mathrm{yr}$. The response at the northern well (D-1709 02DDA1) is more tightly delimited temporally, having positive correlations occurring between 15 and $17 \mathrm{yr}$ and also between 24.5 and $26 \mathrm{yr}$. The maximum for the northern well is about $25 \mathrm{yr}(r=0.34)$. The fact that correla-tion maxima occur over two tightly constrained ranges indicates that recharge to this location does not originate from widely temporally or spatially distributed sources. The shorter overall lag time in the southern well, which indicates a shorter distance to the 


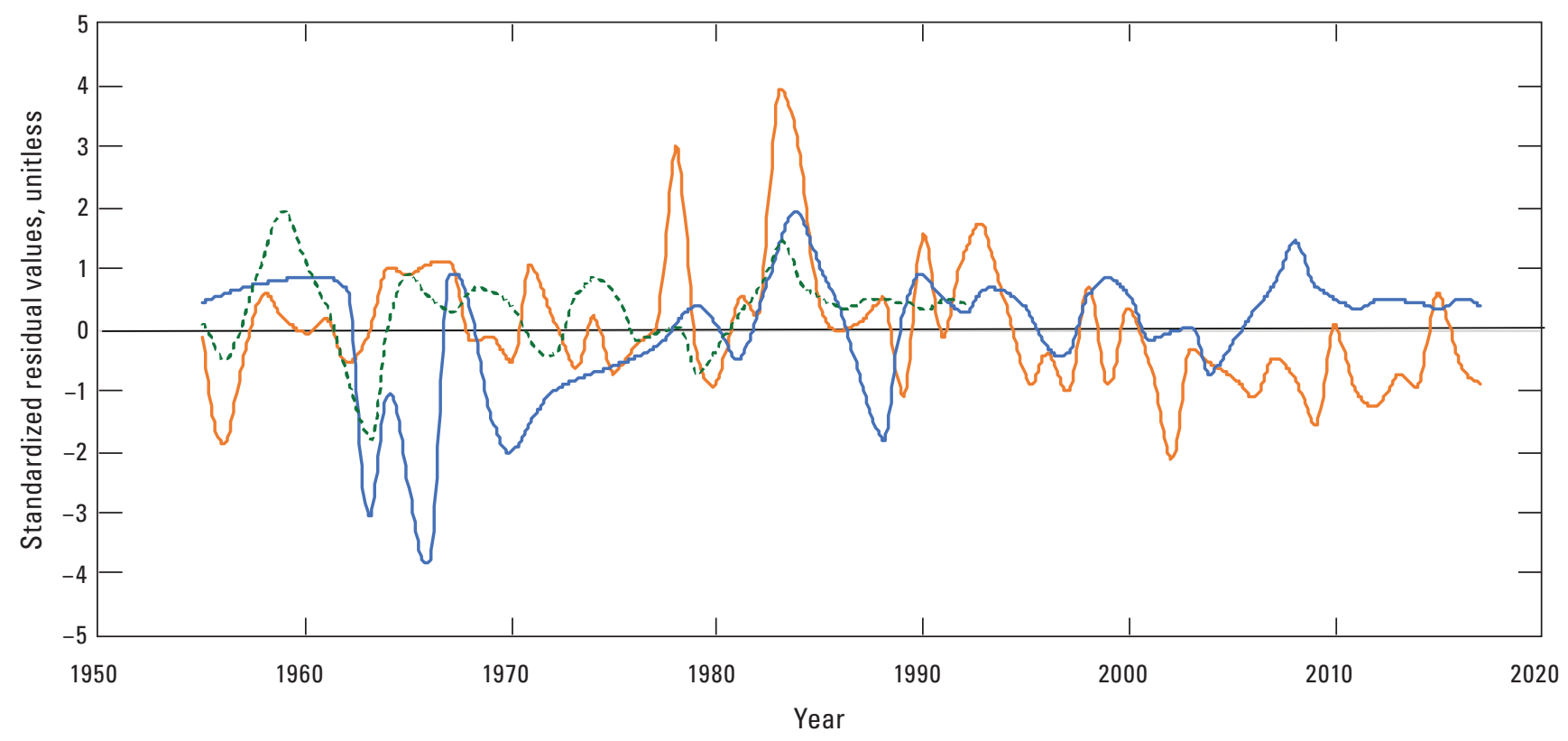

EXPLANATION

Figure 14. Plot of lag correlation analysis (Dickinson and others, 2014), showing unitless standardized residual values of (1) precipitation, (2) groundwater levels at well D-17-09 02DDA1 in northern part of Altar Valley, Arizona, and (3) groundwater levels lagged 25 years.

recharge source, could be one reason that wells in the south are experiencing drought-driven declines in water levels earlier than the northern wells do. This may indicate that the decline in water levels, or at least the groundwater deficit, will eventually propagate to the northern part of the aquifer.

The current drought in southwestern North America is among the most severe to strike the region in the last 1,200 yr (Williams and others, 2020). Climate simulations for the next few decades predict both increased temperatures and reduced precipitation in southwestern North America (Gramling, 2020). The future effects of changes in land cover, land use, pumping, and climate on trends of aquifer storage-groundwater levels are unknown. Given the complexity and uncertainty of the effects of these factors, it is possible that conceptual and numerical groundwater models could be used as relatively inexpensive tools to explore the effects of climate, development, and conservation-restoration scenarios on the hydrology of the study area.

\section{Summary}

This study was undertaken by the USGS in cooperation with the USFWS to summarize what is known about the geohydrologic system on the Buenos Aires National Wildlife Refuge and analyze groundwater-level trends and any precipitation-groundwater correlations to learn about the effects of the two-decade-long drought that began in 2000 on groundwater levels in Altar Valley. In addition, available data were compiled where possible on the climate, land cover, soils, geology, and hydrology to provide a foundation for future studies of the system.

The early 1980s brought decreased storage in the Altar Valley groundwater system. The Arizona Groundwater Act was passed in 1980, which increased regulation on pumpage, and higher than average precipitation occurred in the early 1980s. These events were followed by two decades of drought that began in 2000. The larger effects of reduced pumpage from the Arizona Groundwater Act occurred on the municipal and agricultural wells in northern Altar Valley where the City of Tucson took over agricultural wells and, later, ended production when some were converted to monitoring wells. The southern part of Altar Valley contains substantially fewer large, producing wells.

Drought, with increasing temperatures and decreasing precipitation, can cause decreases in surface-water runoff and groundwater recharge. Decreased groundwater recharge in the study area is likely the cause of increasing depth to water in wells. Declining groundwater levels resulting from prolonged drought are most prevalent in the southern part of Altar Valley. This effect on water levels weakens toward the northern part of the valley. The mountains that bound the west side of the northern part of the valley have higher elevations and receive more precipitation than those that bound the southern part of the valley, and they likely have higher rates of groundwater recharge, contributing to less drawdown. More wells are present in the southern part of Altar Valley, 
along the base of the western mountains, which intercept groundwater flow. Streamflow measured at both the Altar Wash gaging station and the Brawley Wash gaging station has decreased since 2000 , likely as a result of the ongoing drought. In the southern part of Altar Valley, aquifer sediments are coarse grained, and the basin is shallow, having depths that generally are less than 1,600 feet (ft). In northern part of Altar Valley, sediments are finer grained, and the basin is deeper, having depths that exceed 4,800 $\mathrm{ft}$. Annual pumpage in the southern part of the basin has been relatively steady during the drought, whereas downgradient, in the northern part of the basin, pumpage has increased.

Annual groundwater pumpage decreased substantially in the northern part of the valley, beginning in the early 1980s, but began to increase again in the 1990s, whereas pumpage in the southern part has remained comparatively low and steady. Although the exact reasons for the declining groundwater levels in the southern part are unclear, they may be affected by climate cycles, long-term drought, and increases in evapotranspiration. Lag-correlation analysis of annual precipitation and groundwater levels showed a lag of about 17 years (yr) in the southern part of the valley and about $25 \mathrm{yr}$ in the northern part. As to the comparatively stable groundwater levels in the northern part, although pumpage has increased there since the 1990s, it is still about one-half of what it was in the early 1980s. Water levels in most wells in the northern part were drawn down prior to the decrease in pumping. Water levels were in the process of recovering when the increase in pumping occurred in the 1990s. Because the water levels were recovering, the increased pumping may have only limited the recovery rather than cause a decline. Additional possible causes for the stability in groundwater levels include (1) an upgradient aquifer transmissivity high enough to offset pumping, (2) a low-permeability barrier at the north end of the valley that impedes northward flow, (3) a higher lateral-groundwater inflow in the northern part of the valley, (4) a delay in the effect of storage declines that propagate from the southern part, or (5) some combination thereof.

Temporal patterns of groundwater-level changes result from the combined effects of changes in temperature, pumping, and amounts of precipitation, runoff, and recharge. Continuation of groundwater monitoring in Altar Valley would be beneficial to track ongoing declines (or increases) in groundwater levels in the southern part of the valley. With predictions for both increased temperatures and reduced precipitation in southwestern North America, continued and prolonged drought may cause the declines in groundwater storage to propagate from the northern part of the valley into the southern part. A groundwater-flow model could be used to explore climate- and pumping-induced changes in the groundwater system over time. Likewise, it could be used to understand land-use and land-cover changes, including conservation and restoration measures such as controlled burns and enhanced aquifer recharge.

\section{Selected References}

Andrews, D.A., 1937, Ground water in Avra-Altar Valley, Arizona: U.S. Geological Survey Water Supply Paper 796-E, p. 163-180. [Also available at https://pubs.er.usgs. gov/publication/wsp796E.]

Arizona Department of Water Resources [ADWR], 2017, Statewide groundwater level changes in Arizona, water years 1996 to 2016, 2006 to 2016, and 2015 to 2016: Arizona Department of Water Resources Open-File Report No. 14, 30 p., 17 pls., 4 appendixes, last accessed March 2020 at https://new.azwater.gov/sites/default/files/WL_ Change_Report_Final.pdf.

Arizona Department of Water Resources [ADWR], 2020, Query of pumpage by each well by AMA and year parameters: Arizona Department of Water Resources database, accessed April 2, 2020, at https://www.azwater. gov/querycenter/query.aspx?qrysessionid $=9 \mathrm{D} 766144 \mathrm{C} 04 \mathrm{C} 8$ E37E0534C64850A58D9.

Arizona Meteorological Network, 2020, Sahuarita station data and reports, in AZMET - The Arizona Meteorological Network: The University of Arizona College of Agriculture and Life Sciences website, last accessed March 2020 at https://cals.arizona.edu/azmet/38.htm.

Arizona State Climate Office, 2019, Arizona drought: Arizona State Climate Office website, accessed June 28, 2019, at https://azclimate.asu.edu/drought/.

Bryan, K., 1925, The Papago Country, Arizona-A geographic, geologic, and hydrologic reconnaissance with a guide to desert watering places: U.S. Geological Survey Water-Supply Paper 499, 436 p., last accessed March 2020 at https://pubs.usgs.gov/wsp/0499/report.pdf.

CONAGUA (Comisión Nacional del Agua), 2018, Actualización de la disponibilidad media anual de agua en el acuífero Arroyo Seco (2607), Estado de Sonora: Publicada en el Diario Oficial de la Federación, el Enero de 2018, $21 \mathrm{p}$.

Corkhill, F., 2012, Final report—Statewide hydrologic monitoring report (late 1980s early/mid 1990s to mid/ late 2000s): Arizona Department of Water Resources, 81 p., 3 appendixes, last accessed March 2020 at https:// new.azwater.gov/sites/default/files/ADWR_Statewide_ Hydrologic_Monitoring_Report_June_2012_revision.pdf.

Daly, C., Halbleib, M., Smith, J.I., Gibson, W.P., Doggett, M.K., Taylor, G.H., Curtis, J., and Pasteris, P.P., 2008, Physiographically sensitive mapping of climatological temperature and precipitation across the conterminous United States: International Journal of Climatology, v. 28, no. 15, p. 2031-2064, last accessed March 2020 at https://doi.org/10.1002/joc.1688. 
Davis, T., Dieckhoff, J., and Stuk, S., 2014, Statewide groundwater level changes in Arizona, water years 1993 to 2013, 2003 to 2013, and 2012 to 2013: Arizona Department of Water Resources Open-File Report No. 13, 32 p., 18 pls., 6 appendixes, last accessed March 2020 at https://new. azwater.gov/sites/default/files/OFR_13_Edits_0.pdf.

Dickinson, J.E., Hanson, R.T., and Predmore, S.K., 2014, HydroClimATe-Hydrologic and climatic analysis toolkit: U.S. Geological Survey Techniques and Methods, book 4, chap. A9, 49 p., last accessed March 2020 at https://doi. org/10.3133/tm4a9.

Eastoe, C.J., and Wright, W.E., 2019, Hydrology of mountain blocks in Arizona and New Mexico as revealed by isotopes in groundwater and precipitation: Geosciences, v. 9, no. 461, 22 p., last accessed March 2020 at https://doi. org/10.3390/geosciences 9110461 .

Freeze, R.A., and Cherry, J.A., 1979, Groundwater: Englewood Cliffs, N.J., Prentice-Hall, 604 p.

Fuller, J.E., 2016, Altar Wash restoration conceptual evaluation of alternative methods: Hydrology \& Geomorphology Inc, $39 \mathrm{p}$.

Gilbert, R.O., 1987, Statistical methods for environmental pollution monitoring: New York, Van Nostrand Reinhold, $336 \mathrm{p}$.

Glenn, E.P., Scott, R.L., Nguyen, U., and Nagler, P.L., 2015, Wide-area ratios of evapotranspiration to precipitation in monsoon-dependent semiarid vegetation communities: Journal of Arid Environments, v. 117, p. 84-95, last accessed March 2020 at https://doi.org/10.1016/j. jaridenv.2015.02.010.

Gramling, C., 2020, Climate change made a southwestern U.S. drought one of the worst in 1,200 years: Science News, v. 197, no. 9, p. 8, accessed April 17, 2020, at https://www. sciencenews.org/article/climate-change-made-southwesternu-s-drought-worst-1200-years.

Granato, G.E., Ries, K.G., III, and Steeves, P.A., 2017, Compilation of streamflow statistics calculated from daily mean streamflow data collected during water years 19012015 for selected U.S. Geological Survey streamgages: U.S. Geological Survey Open-File Report 2017-1108, 17 p., last accessed March 2020 at https://doi.org/10.3133/ ofr 20171108 .

Hammett, B.A., and Sicard, J.W., 1995, Maps showing groundwater conditions in the Santa Cruz and Tucson Active Management Areas-Pima, Pinal, and Santa Cruz Counties: Arizona Department of Water Resources OpenFile Report No. 8, 4 sheets, last accessed March 2020 at https://new.azwater.gov/sites/default/files/Report $\% 20$ No.\%208.pdf.
Hanson, R.T., 1996, Postaudit of head and transmissivity estimates and ground-water flow models of Avra Valley, Arizona: U.S. Geological Survey Water-Resources Investigations Report 96-4045, 84 p., last accessed March 2020 at https://doi.org/10.3133/wri964045.

Haxel, G., May, D.J., and Tosdal, R.M., 1982, Reconnaissance geologic map of the Presumido Peak quadrangle, Arizona: U.S. Geological Survey Miscellaneous Field Studies Map MF-1378, scale 1:62,500, last accessed March 2020 at https://ngmdb.usgs.gov/Prodesc/proddesc_7064.htm.

Keith, W.J., and Theodore, T.G., 1975, Reconnaissance geologic map of the Arivaca quadrangle, Arizona: U.S. Geological Survey Miscellaneous Field Studies Map MF-678, scale 1:63,360, last accessed March 2020 at https://ngmdb.usgs.gov/Prodesc/proddesc_3813.htm.

Lysonski, J.C., Sumner, J.S., Aiken, C., and Schmidt, J.S., 1980, Residual Bouguer gravity anomaly map of Arizona (IGSN 71): University of Arizona Geophysical Society, scale 1:1,000,000, last accessed March 2020 at http:// repository.azgs.az.gov/sites/default/files/dlio/files/nid1558/ bouguergravaz1980.pdf.

Moosburner, O., 1972, Analysis of the ground-water system by electrical-analog model, Avra Valley, Pima and Pinal Counties, Arizona: U.S. Geological Survey Hydrologic Investigations Atlas HA-215, 2 sheets, last accessed March 2020 at https://doi.org/10.3133/ha215.

National Weather Service, 2019, Monthly rainfall normals (1981-2010) across Southeast Arizona: National Oceanic and Atmospheric Administration, National Weather Service website, accessed June 28, 2019, at https://www.wrh.noaa. gov/twc/climate/seaz_rainfall_normals.php.

National Weather Service Forecast Office, 2020a, Threemonth temperature outlook, Tucson, AZ-Anvil Ranch, AZ: National Oceanic and Atmospheric Administration, National Weather Service website, accessed June 1, 2020, at https://w2.weather.gov/climate/calendar_outlook. php?wfo $=$ twc\&site $=20287$.

National Weather Service Forecast Office, 2020b, Threemonth temperature outlook, Tucson, AZ - Kitt Peak, AZ: National Oceanic and Atmospheric Administration, National Weather Service website, accessed June 1, 2020, at https://w2.weather.gov/climate/calendar_outlook. $\mathrm{php}$ ?wfo $=$ twc\&site $=24675$.

National Weather Service Forecast Office, 2020c, Threemonth temperature outlook, Tucson, AZ-Sasabe, AZ: National Oceanic and Atmospheric Administration, National Weather Service website, accessed June 1, 2020, at https://w2.weather.gov/climate/calendar_outlook. php?wfo=twc\&site $=27619$. 
Oppenheimer, J.M., and Sumner, J.S., 1980, Depth-tobedrock map, Basin and Range province, Arizona: Tucson, University of Arizona, Department of Geosciences, scale $1: 1,000,000$.

Owen-Joyce, S.J., 2021, Groundwater well data and annual groundwater pumpage data (1984 - 2019) in Altar Valley, Arizona: U.S. Geological Survey data release, https://doi. org/10.5066/P9QST8OX.

Paretti, N.V., Kennedy, J.R., Turney, L.A., and Veilleux, A.G., 2014, Methods for estimating magnitude and frequency of floods in Arizona, developed with unregulated and rural peak-flow data through water year 2010: U.S. Geological Survey Scientific Investigations Report 2014-5211, 61 p., last accessed March 2020 at https://doi.org/10.3133/ sir20145211.

Pima Association of Governments Watershed Planning, 2006, Hydrogeologic assessment of Arivaca: accessed September 19, 2019, at https://www.pagnet.org/Documents/Water/ ArivacagwhydroFinal.pdf.

PRISM Climate Group, 2019, PRISM climate data [Norm81m, AN81m, AN81d]: Corvalis, Oregon State University, Northwest Alliance for Computational Science and Engineering PRISM Climate Group website, accessed July 19, 2019, at https://www.prism.oregonstate.edu/ explorer/.

Reeter, R.W., and Cady, C.V., 1982, Maps showing groundwater conditions in the Avra/Altar Valley area, Pima and Santa Cruz Counties, Arizona - 1981: Arizona Department of Water Resources Hydrologic Map Series Report No. 7, 2 sheets, last accessed March 2020 at https://new.azwater. gov/sites/default/files/HMS_No_7.pdf.

Richard, S.M., Reynolds, S.J., Spencer, J.E., and Pearthree, P.A., comps., 2000, Geologic map of Arizona: Arizona Geological Survey Map 35, scale 1,000,000, last accessed March 2020 at http://repository.azgs.az.gov/sites/default/ files/dlio/files/nid1705/geologic_map_of_az_-_m35_1.jpg.

Richard, S.M., Shipman, T.C., Greene, L.C., and Harris, R.C., 2007, Estimated depth to bedrock in Arizona: Arizona Geological Survey Digital Geologic Series DGM-52, version 1.0, 8 p., scale 1,000,000, last accessed March 2020 at http://repository.azgs.az.gov/uri_gin/azgs/dlio/584 .

Salmi, T., Määttä, A., Anttila, P., Ruoho-Airola, T., and Amnell, T., 2002, Detecting trends of annual values of atmospheric pollutants by the Mann-Kendall test and Sen's slope estimates-The Excel template application MAKESENS: Finnish Meteorological Institute Publications on Air Quality No. 31, 35 p.

Sauck, W.A., and Sumner, J.S., 1970, Residual aeromagnetic map of Arizona: Tucson, University of Arizona Geophysical Society, scale 1:1,000,000, last accessed March 2020 at http://repository.azgs.az.gov/sites/default/files/dlio/files/ nid1557/aerialmagaz-300dpi.pdf.
Schorr, S.W., 2005, Hydrologic assessment and simulations of groundwater conditions in Arivaca Basin, Pima County, Arizona: Tucson, University of Arizona Department of Hydrology and Water Resources, M.S. thesis, 128 p., accessed September 23, 2019, at https://azgs.arizona. edu/azgeobib/hydrologic-assessment-and-simulationsgroundwater-conditions-arivaca-basin-pima-county.

Soil Science Division Staff, U.S. Department of Agriculture [SSD USDA], 2017, Soil survey manual: Washington, D.C., Government Printing Office, U.S. Department of Agriculture Handbook No. 18, 603 p.

Soil Survey Staff, U.S. Department of Agriculture [SSS USDA], 2019a, Official soil series descriptions: U.S. Department of Agriculture, Natural Resources Conservation Service, accessed September 1, 2019, at https://soilseries. sc.egov.usda.gov.

Soil Survey Staff, U.S. Department of Agriculture [SSS USDA], 2019b, Soil Survey geographic (SSURGO) database [for Arizona]: U.S. Department of Agriculture, Natural Resources Conservation Service, last accessed March 2020 at https://www.nrcs.usda.gov/wps/portal/nres/ detail/vt/soils/?cid=nrcs142p2_010596\#Datamart.

Soil Survey Staff, U.S. Department of Agriculture [SSS USDA], 2019c, U.S. General soil map (STATSGO2): U.S. Department of Agriculture, Natural Resources Conservation Service, accessed March 6, 2019, at https://sdmdataaccess. sc.egov.usda.gov.

Thomas, H.E., 1962, The meteorologic phenomenon of drought in the southwest, chap. A in Drought in the southwest, 1942-56: U.S. Geological Survey Professional Paper 372-A, 43 p., accessed May 14, 2021, at https://doi. org/10.3133/pp372A.

Tillman, F.D., Cordova, J.T., Leake, S.A., Thomas, B.E., and Callegary, J.B., 2011, Water availability and use pilot-Methods development for a regional assessment of groundwater availability, southwest alluvial basins, Arizona: U.S. Geological Survey Scientific Investigations Report 2011-5071, 118 p., last accessed March 2020 at https://doi. org/10.3133/sir20115071.

Turner, S.F., 1947, Further investigations of the ground-water resources of the Santa Cruz Basin, Arizona: U.S. Geological Survey Open-File Report, 45 p.

Turner, S.F., and others, 1943, Ground-water resources of the Santa Cruz Basin, Arizona: U.S. Geological Survey OpenFile Report [unnumbered], 84 p., 3 pls., scales 1:23,000, $1: 200,000,1: 500,000$. 
U.S. Department of Agriculture, Natural Resources Conservation Service [USDA NRCS], 2020, National soil survey handbook, title 430-VI: U.S. Department of Agriculture, Natural Resources Conservation Service, accessed September 23, 2020, at https://www.nrcs.usda.gov/ wps/portal/nrcs/detail/soils/ref/?cid=nrcs142p2_054242.

U.S. Geological Survey [USGS], 2018, National Hydrography -Access National Hydrography products: U.S. Geological Survey National Hydrography website, accessed October 18, 2018, at https://www.usgs.gov/core-science-systems/ ngp/national-hydrography/access-national-hydrographyproducts.

U.S. Geological Survey [USGS], 2019a, USGS water data for the Nation: U.S. Geological Survey National Water Information System database, accessed February 12, 2020, at https://doi.org/10.5066/F7P55KJN.

U.S. Geological Survey [USGS], 2019b, USGS water data for the Nation: U.S. Geological Survey National Water Information System database, last accessed September 11, 2019, at https://doi.org/10.5066/F7P55KJN.

U.S. Geological Survey [USGS], 2020, USGS water data for the Nation: U.S. Geological Survey National Water Information System database, last accessed May 5, 2020, at https://doi.org/10.5066/F7P55KJN.

Western Regional Climate Center, 2021, US COOP Station Map: Western Regional Climate Center website, accessed April 18, 2021, at https://wrcc.dri.edu/coopmap/\#.

West Wide Drought Tracker, 2020a, Western United States, Mean Temperature-November-January 2021 percentile: Moscow, University of Idaho, Western Regional Climate Center website, last accessed March 2020 at https://wrcc. dri.edu/wwdt/archive.php?folder=mdn3per.
West Wide Drought Tracker, 2020b, Western United States, Precipitation-November-January 2021 percentile: Moscow, University of Idaho, Western Regional Climate Center website, last accessed March 2020 at https://wrcc. dri.edu/wwdt/archive.php?folder=pon3per.

White, N.D., Matlock, W.G., and Schwalen, H.C., 1966, An appraisal of the ground-water resources of Avra and Altar Valleys, Pima County, Arizona: Arizona State Land Department Water-Resources Report 25, 66 p.

Wilson, E.D., Moore, R.T., and Cooper, J.R., 1969, Geologic map of Arizona: Arizona Bureau of mines map, scale $1: 500,000$

Wilson, R.P., 1991, Summary of ground-water conditions in Arizona 1985-86: U.S. Geological Survey Water-Resources Investigations Report 90-4179, 4 sheets.

Williams, A.P., Cook, E.R., Smerdon, J.E., Cook, B.I., Abatzoglou, J.T., Bolles, K., Baek, S.H., Badwger, A.M., and Livneh, B., 2020, Large contribution from anthropogenic warming to an emerging North American megadrought: Science, v. 368 , no. 6488 , p. 314-318, accessed April 17, 2020, at https://science.sciencemag.org/ content $/ 368 / 6488 / 314$.

Yang, L., Jin, S., Danielson, P., Homer, C., Gass, L., Case, A., Costello, C., Dewitz, J., Fry, J., Funk, M., Grannemann, B., Rigge, M., and Xian, G., 2018, A new generation of the United States National Land Cover Database-Requirements, research priorities, design, and implementation strategies: ISPRS Journal of Photogrammetry and Remote Sensing, v. 146, p. 108-123. 


\section{Appendix 1. Selected Well Data in the Altar Valley, Arizona, Groundwater Area}

\author{
Selected well data in the Altar Valley, Arizona, ground- \\ water area (ALT) (as delineated by U.S. Geological Survey) \\ are provided in the data release (Owen-Joyce, 2021; see table \\ entitled, "Groundwater Well Data for Altar Valley.xlsx") \\ associated with this report. Well data are from National Water \\ Information System (NWIS) database (U.S. Geological Sur- \\ vey, 2020); locations are shown in figure 5 (this report). Note \\ that not all well data were updated outside the Buenos Aires \\ National Wildlife Refuge in Altar Valley because of funding \\ constraints.
}

\section{References Cited in Appendix 1}

Owen-Joyce, S.J., 2021, Groundwater well data and annual groundwater pumpage data (1984 - 2019) in Altar Valley, Arizona: U.S. Geological Survey data release, https://doi. org/10.5066/P9QST8OX.

U.S. Geological Survey, 2020, USGS water data for the Nation: U.S. Geological Survey National Water Information System database, last accessed May 5, 2020, at https://doi. org/10.5066/F7P55KJN. 


\section{Appendix 2. Annual Groundwater Pumpage in Altar Valley, Arizona, Between 1984 and 2019}

Annual groundwater pumpage in the Altar Valley, Arizona, groundwater area (ALT) (as delineated by U.S. Geological Survey) between 1984 and 2019 are provided in the data release (Owen-Joyce, 2021; see table entitled, "Groundwater Annual Pumpage in Altar Valley.xlsx") associated with this report. Data are modified (summarized) from Arizona Department of Water Resources (2020).

\section{References Cited in Appendix 2}

Arizona Department of Water Resources, 2020, Query of pumpage by each well by AMA and year parameters:

Arizona Department of Water Resources database, accessed April 2, 2020, at http://www.azwater.gov/querycenter/query. aspx?qrysessionid $=9 \mathrm{D} 766144 \mathrm{C} 04 \mathrm{C} 8 \mathrm{E} 37 \mathrm{E} 0534 \mathrm{C} 64850 \mathrm{~A}$ $58 \mathrm{D} 9$.

Owen-Joyce, S.J., 2021, Groundwater well data and annual groundwater pumpage data (1984 - 2019) in Altar Valley, Arizona: U.S. Geological Survey data release, https://doi. org/10.5066/P9QST8OX. 
Moffett Field Publishing Service Center, California

Manuscript approved for publication May 13, 2021

Edited by Taryn A. Lindquist

Layout and design by Kimber Petersen 
कृ

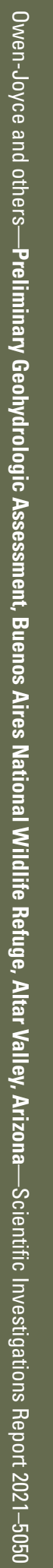

ISSN 2328-0328 (online) 